\title{
Do European agroforestry systems enhance biodiversity and ecosystem services? A meta-analysis
}

This is a pre-print version of the following paper:

Torralba, M., Fagerholm, N., Burgess, P.J., Moreno, G., Plieninger, T. (2016). Do European agroforestry systems enhance biodiversity and ecosystem services? A meta-analysis. Agriculture, Ecosystems and Environment 230: 150-161. http://dx.doi.org/10.1016/j.agee.2016.06.002

\begin{abstract}
Agroforestry has been proposed as a sustainable agricultural system over conventional agriculture and forestry, conserving biodiversity and enhancing ecosystem service provision while not compromising productivity. However, the available evidence for the societal benefits of agroforestry is fragmented and does often not integrate diverse ecosystem services into the assessment. To upscale existing case-study insights to the European level, we conducted a meta-analysis on the effects of agroforestry on ecosystem service provision and on biodiversity levels. From 53 publications we extracted a total of 365 comparisons that were selected for the meta-analysis. Results revealed an overall positive effect of agroforestry (effect size $=0.454, p<0.01$ ) over conventional agriculture and forestry. However, results were heterogeneous, with differences among the types of agroforestry practices and ecosystem services assessed. Erosion control, biodiversity, and soil fertility are enhanced by agroforestry while there is no clear effect on provisioning services. The effect of agroforestry on biomass production is negative. Comparisons between agroforestry types and reference land-uses showed that both silvopastoral and silvoarable systems increase ecosystem service provision and biodiversity, especially when compared with forestry land. Mediterranean tree plantation systems should be especially targeted as soil erosion could be highly reduced while soil fertility increased. We conclude that agroforestry can enhance biodiversity and ecosystem service provision relative to conventional agriculture and forestry in Europe and could be a strategically beneficial land use in rural planning if its inherent complexity is considered in policy measures.
\end{abstract}

Keywords: land use management, systematic review, silvopastoral systems, silvoarable systems, agroecosystem 


\subsection{Introduction}

Agroforestry is the practice of deliberately integrating woody vegetation (trees or shrubs) with crop and/or animal production systems to benefit from the resulting ecological and economic interactions (Mosquera-Losada et al., 2009). Agroforestry has played an important role in Europe in the past, and traditional agroforestry practices, such as wood pasture and grazed or intercropped orchards, are still practised widely in Europe (Mosquera-Losada et al., 2009). However, during the 20th century, the area of many European agroforestry systems decreased while the remaining agroforestry practices are vulnerable (Nerlich et al., 2013). The Common Agricultural Policy (CAP) and other public policies have frequently accelerated a transition to specialised forms of agriculture and forestry (van Zanten et al., 2013).

The requirement to conserve biodiversity has been agreed on at an international level, and the Europe 2020 strategy for a "resource efficient" Europe (European Comission, 2011) highlights the necessity of protecting, valuing, and restoring biodiversity and ecosystem services. One of the key concepts for examining the interactions between biodiversity and ecological systems such as agriculture and forestry is the ecosystem service framework (Millennium Ecosystem Assessment, 2005). This framework highlights how biodiversity leads to a range of services that benefit human well-being, including food and fibre production and regulating and cultural services.

The need to combine production with environmental enhancement can provide an opportunity for a renaissance of agroforestry. Agroforestry can sometimes increase land productivity as the combination of tree and crop systems leads to a more efficient capture of resources (such as solar radiation or water) than separated tree or crop systems (Cannell et al., 1996, Graves et al., 2007, Jose 2009). However neutral and negative interactions have been also reported (e.g. Jose et al., 2004; Rivest et al., 2013). Agroforestry has also been found to improve regulating ecosystem services such as nutrient retention, erosion control, carbon sequestration, pollination, pest control and fire risk reduction, and cultural services such as an increase in recreational, aesthetic, and cultural heritage values (McAdam et al., 2009; Smith et al., 2012; Tsonkova et al., 2012). In line with this, in 2005, the European Union provided opportunity for national and regional governments to financially support the establishment of new agroforestry systems (European Union 2013).

The interactions between biodiversity, ecosystem services, and agroforestry have been previously explored. Tsonkova et al. (2012) reviewed the ecosystem services supplied by alley cropping in temperate regions, but this is only one type of agroforestry. Lorenz and Lal (2014) described the role of agroforestry systems in soil carbon sequestration estimating that agroforestry might may be sequestering up to $2.2 \mathrm{Pg}$ of Carbon above- and belowground over 50 years, but did not consider other ecosystem services. After two decades of research on agroforestry functioning in Europe, the aim of this paper is to report on a formal meta-analysis of the evidence that agroforestry systems increase the provision of ecosystem services in Europe compared to other conventional agriculture and forestry systems. Within the ecosystem service framework used by the Millennium Ecosystem Assessment (2005), biodiversity is assumed to be the source of ecosystem services. Schneiders et al. (2012) describes biodiversity and ecosystem service provision as being intricately linked, and within the UK National Ecosystem Assessment (2011) wild species diversity is included as a provisioning/cultural service. Hence this current study considers both biodiversity and ecosystem services in relation to agroforestry. It is anticipated that this analysis will help to identify the generality of existing case-study findings and the presence of large scale patterns. Specifically we raise the following research questions:

Does European agroforestry enhance biodiversity and ecosystem services relative to conventional agriculture or forestry (natural and planted forest)?

Which species groups and which categories of ecosystem services are most supported by agroforestry? 
What differences arise among different kinds of agroforestry (e.g. silvoarable systems, silvopastoral agroforestry)?

Do biophysical system properties such as temperature and precipitation drive inter-site differences?

This study can contribute to empower agroforestry towards future agricultural policies providing policy makers and practitioners concrete examples where agroforestry could be a sustainable solution over conventional agriculture and forestry.

\subsection{Material and methods}

\subsubsection{Study selection}

The methodology followed existing guidelines for systematic review and literature mapping (Pullin \& Stewart, 2006; Pullin \& Knight, 2009; Centre of Evidence-based Conservation, 2010; Bilotta et al., 2014). The benefit of a systematic review, as opposed to one unsystematic, is that it uses a process that is more objective and transparent. A review protocol was produced following recommendations describing the systematic literature search and inclusion criteria (Annex A). The systematic literature mapping sought to include all scientific publications that provide quantitative data comparing agroforestry with an alternative land use system in a European study area and using indicators that assess biodiversity and ecosystem services (Table 1).

Table 1. Inclusion criteria

\begin{tabular}{|l|l|}
\hline $\begin{array}{l}\text { Agroforestry } \\
\text { systems }\end{array}$ & $\begin{array}{l}\text { Every kind of system that follows this definition: agroforestry is the practice of } \\
\text { deliberately integrating woody vegetation (trees or shrubs) with crop and/or animal } \\
\text { production systems to benefit from the resulting ecological and economic } \\
\text { interactions. This means that the following systems were included: silvoarable } \\
\text { systems, silvopastoral agroforestry, agro-silvopastoral systems, buffer strips } \\
\text { (which use woody elements) and multipurpose trees systems (Mosquera-Losada } \\
\text { et al., 2009). }\end{array}$ \\
\hline $\begin{array}{l}\text { Types of } \\
\text { comparable } \\
\text { land use }\end{array}$ & $\begin{array}{l}\text { The compared system must be a conventional farmland or a forestry system with } \\
\text { very low cover of agroforestry within the same region. }\end{array}$ \\
\hline $\begin{array}{l}\text { Geographical } \\
\text { scope }\end{array}$ & The study areas were limited to Europe in a geographical sense \\
\hline $\begin{array}{l}\text { Methodologica } \\
\text { approach }\end{array}$ & $\begin{array}{l}\text { Only studies that perform quantitative biodiversity and ecosystem service } \\
\text { assessment based on primary data. }\end{array}$ \\
\hline
\end{tabular}

Initially, the meta-analysis aimed to analyze the effect of agroforestry on the provision of ecosystem services categories present in the Millennium Ecosystem Assessment (Annex A). However, we early found in initial tests that our analysis would need to be narrowed due to a lack of primary studies analyzing the effect of agroforestry on many ecosystem service categories. The need of at least three primary studies targeting the same ecosystem service reduced the initial scope which included a wider range of ecosystem services (including air and water purification, pollination, pest regulation and all cultural ecosystem services) to the final selection: timber production, food production, biomass production, soil fertility and nutrient cycling, erosion control and biodiversity.

The literature search was performed in August 2014 by generating combinations of keywords in three databases: ISI Web of Science, SCOPUS and CAB Abstracts. We additionally included the first 50 documents provided by Google Scholar and in the end of the process added five papers recommended by three experts in the field. The systematic search included three strings in English: 1) definitions and terms used to describe European agroforestry systems, 2) terms describing ecosystem services and biodiversity indicators used to measure them, and 3) Europe and a set of European countries (Table 2). Titles and abstracts were stored in an EndNote database where duplicates were removed. To ensure the inclusion criteria were consistently followed during the publication selection process, a $10 \%$ subset of the whole database was assessed by an independent reviewer. 
Table 2. Search terms applied to title, abstract and keywords in the specified databases

\begin{tabular}{|c|c|}
\hline Search string & Terms \\
\hline 1 & 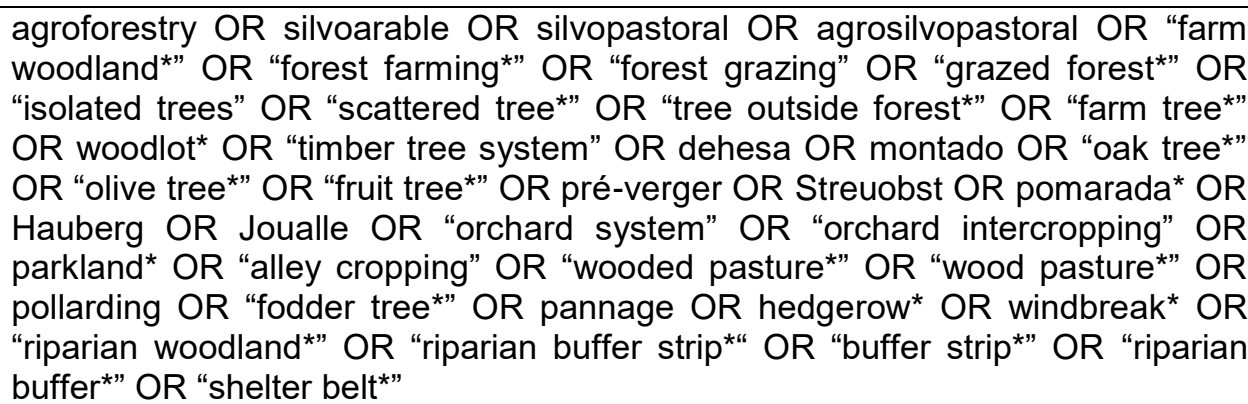 \\
\hline 2 & $\begin{array}{l}\text { Product* OR Provision* OR "Soil formation" OR "soil organic carbon" OR "soil } \\
\text { carbon" OR "soil C" OR "soil organic C" OR SOC OR "carbon pool" OR "carbon } \\
\text { stock" OR "carbon storage" OR "soil organic matter" OR SOM, "carbon } \\
\text { sequestrat"” OR "C sequestrat*" OR "Nutrient cycling" OR "Nutrient retention" } \\
\text { OR "soil services" OR Nitrogen OR Phosphorus OR Erosion OR "soil loss" OR } \\
\text { "water quality" OR "water regulation" OR "water purification" OR "hydrological } \\
\text { regulation" OR Biodiversity OR richness OR "species abundance" OR "species } \\
\text { composition" OR "biological diversity" }\end{array}$ \\
\hline 3 & $\begin{array}{l}\text { Europe }^{*} \text { OR EU OR Albania OR Andorra OR Armenia OR Austria OR } \\
\text { Azerbaijan OR Belarus OR Belgium OR "Bosnia and Herzegovina" OR Bulgaria } \\
\text { OR Croatia OR Cyprus OR Czech* OR Denmark OR Estonia OR Finland OR } \\
\text { France OR Georgia OR Germany OR Greece OR Hungary OR Iceland OR } \\
\text { Ireland OR Italy OR Kazakhstan OR Latvia OR Liechtenstein OR Lithuania OR } \\
\text { Luxembourg OR Malta OR Moldova OR Monaco OR Montenegro OR } \\
\text { Netherlands OR Norway OR Poland OR Portugal OR Romania OR Russia OR } \\
\text { "San Marino" OR Serbia OR Slovak* OR Slovenia OR Spain OR Sweden OR } \\
\text { Switzerland OR Macedonia OR Turkey OR Ukraine OR "United Kingdom" OR } \\
\text { England OR Wales OR Scotland }\end{array}$ \\
\hline
\end{tabular}

The final number of primary studies included in the analysis was refined through a three-step process: 1) the title and keywords, 2) the abstracts and 3) the full publication content. In each phase, publications that fulfilled the inclusion criteria (Table 1) were promoted to the next step. The initial search provided a total of 5,235 publications that after the first filter were narrowed down to a total of 604 publications. Ultimately, 53 publications were included in the meta-analysis.

\subsubsection{Data collection}

A meta-analysis compares the quantitative outcomes of different treatments in multiple studies. The contrast between the means is used to summarize the results of the primary studies. Ideally, three values are necessary for this comparison: a mean, a standard deviation and a sample size. Values of each group were extracted directly from the text and tables, taken indirectly from graphs using the DataThief (Tummers, 2006) software, or calculated from raw data when the summary statistics were missing but the original data available. Standard errors were not available in several studies but some were obtained after contacting the authors. Most studies included comparisons of more than one land use or more than one indicator. We considered each comparison as an independent observation in the primary study and use the primary studies as a random factor to control potential correlations between comparisons within a primary study.

For every data record, we derived eight explanatory variables (nine variables in cases where biodiversity was assessed, c.f. Table 3) that served to characterize the properties of those observations and were used as independent variables grouping similar studies in the analysis. If temperature and precipitation were not available in the publication, the study location was used to gather the information from other sources (Global Climate Data - WorldClim, Google Earth). We found that many publications, while not assessing a particular agroforestry system, were interested in 
comparing two areas or landscapes where the main difference was the high/low proportion of agroforestry. These publications were classified under the category of "mixed" for the explanatory variable of agroforestry system type. Although the search strings included terms for agro-silvopastoral systems, buffer strips, and multipurpose trees systems, there were insufficient publications to include these types in the analysis (View Review Protocol, Annex A). This meant that the final categories analyzed for the variable agroforestry system were silvopastoral (trees and livestock), silvoarable (trees and arable crops) and mixed.

Table 3. Explanatory variables extracted from the primary studies and other data sources that were included in the meta-analysis

\begin{tabular}{|l|l|l|}
\hline $\begin{array}{l}\text { Explanatory } \\
\text { variable }\end{array}$ & Description & Source \\
\hline $\begin{array}{l}\text { Agroforestry } \\
\text { system }\end{array}$ & $\begin{array}{l}\text { Agroforestry system on which the study was conducted: } \\
\text { silvoarable systems, silvopastoral systems, and mixed } \\
\text { systems }\end{array}$ & Primary studies \\
\hline Comparator & $\begin{array}{l}\text { Conventional land-use system that the publication used to } \\
\text { compare the agroforestry system against. The three } \\
\text { categories employed were: agricultural land, pasture land, } \\
\text { and forestry land }\end{array}$ & Primary studies \\
\hline Study scale & Extent of the study area (km²) & $\begin{array}{l}\text { Primary } \\
\text { studies/Google } \\
\text { Earth }\end{array}$ \\
\hline $\begin{array}{l}\text { Woody } \\
\text { element }\end{array}$ & Main woody species of the agroforestry system & Primary studies \\
\hline Biodiversity & Taxa studied (Plants/arthropods/fungi/birds) & Primary studies \\
\hline $\begin{array}{l}\text { Biogeographic } \\
\text { region }\end{array}$ & $\begin{array}{l}\text { Biogeographic region in which the study was conducted: } \\
\text { Boreal/Continental/Atlantic/Pannonian/Mediterranean/Alpine }\end{array}$ & Primary studies \\
\hline $\begin{array}{l}\text { Ecosystem } \\
\text { service }\end{array}$ & $\begin{array}{l}\text { Ecosystem service category assessed according to the } \\
\text { Millennium Ecosystem Assessment (2005) framework }\end{array}$ & Primary studies \\
\hline Temperature & Mean annual temperature $\left({ }^{\circ} \mathrm{C}\right)$ & $\begin{array}{l}\text { WorldClim/Primar } \\
\text { y studies }\end{array}$ \\
\hline Precipitation & Mean annual precipitation (mm) & $\begin{array}{l}\text { Worldclim/Primar } \\
\text { y studies }\end{array}$ \\
\hline
\end{tabular}

a Studies in which biodiversity is assessed.

\subsubsection{Response variables}

Two different indices of effect size were used for the meta-analysis: response ratios (Borenstein et al., 2009; Hedges et al., 1999) and Hedges' g (Hedges and Olkin, 1985). Response ratio (Ir) is an unweighted index widely used for meta-analysis in ecology where primary studies differ in the indicators and methods used (De Beenhouwer et al., 2013; Meli et al., 2014; Barral et al., 2015). The response ratio index was defined as the difference between the natural logarithm of the value of a specific indicator in the agroforestry system $(\ln (\mu \mathrm{AF}))$ minus the natural logarithm of the value of the same indicator in the comparison $(\operatorname{In}(\mu \mathrm{C})$ ) (Equation 1). Positives values for Ir indicate positive effects of agroforestry, while negative values for the Ir indicate negative effects.

$$
\operatorname{lr}=\ln (\mu \mathrm{AF})-\ln (\mu \mathrm{C}) . \quad \text { Equation } 1
$$

An increase in the value of an indicator may not always mean benefit. For example if the indicator is soil loss then a decrease in the indicator would usually be preferred. To ensure that high values are correlated with attributes that are desirable from a land management perspective, the algebraic signs of some values were changed.

Hedges' $g$ was used on a subset of publications to analyze the effect of agroforestry on biodiversity. Indicators used to assess biodiversity were homogenous, only including biodiversity richness and abundance. This allowed us to use a more restrictive but precise effect size index. Hedges' g was selected as it as it is not biased by small sample sizes and therefore has been previously used to 
perform meta-analyses based on biodiversity indicators (Paillet et al., 2010; Batáry et al., 2011; De Beenhouwer et al., 2013; Plieninger et al., 2014). Hedges' $g$ is defined as the difference between the means of biodiversity between plots in agroforestry systems $(\mu \mathrm{AF})$ and the land use compared $(\mu \mathrm{C})$, divided by the standard pool deviation of $\mu \mathrm{AF}-\mu \mathrm{C}$ corrected by the sample sizes (s) (Equation 2; Borenstein et al., 2007).

$$
\mathrm{g}=(\mu \mathrm{AF}-\mu \mathrm{C}) / \mathrm{s} \quad \text { Equation } 2 .
$$

Positives values for $\mathrm{g}$ indicate positive effects of agroforestry on biodiversity, while negative values point to negative effects. All the studies included in this biodiversity subgroup analysis were also comprised in the rest of the meta-analysis to see the overall and the explanatory variables effect.

4.2.4 Statistical analysis

To calculate the overall effect of agroforestry on ecosystem service provision and biodiversity, effect sizes were used as dependent variables to construct a random-effect model (effect sizes nested within studies) and calculate the mean effect size assuming random variation among the observations. Hence $95 \%$ confidence intervals were calculated around the mean effect size with bootstrapping of 999 iterations. To assess the effect of the different response variables, sub-group analyses were performed using the explanatory moderators as independent variables (ecosystem service assessed, extent area, agroforestry system, comparator, woody element, biogeographical region, and taxon for comparison regarding biodiversity indicators).

The null hypothesis was examined for the overall meta-analysis and for the subgroup analyses with a two-tail Z-test (i.e. the effect size equals 0 ) and the heterogeneity was analyzed using a Q-test. Finally, a meta-regression was conducted to assess the effect of precipitation and temperature. All of the analysis were performed using Metawin 2.1 (Rosenberg et al., 2000).

In this meta-analysis we compared relatively homogenous subgroups which included almost no variation in the indicator (such as biodiversity with only two kinds of indicator, richness and abundance) with relatively heterogeneous subgroups (like soil fertility with more than 10 different indicators). This artificial grouping should be taken into account when interpreting the results.

We used the fail-safe $\mathrm{N}$ method (Rosenthal, 1979) and calculated a funnel plot comparing effect sizes and variance to visually explore the publication bias (Gurevitch et al., 2001). The Rosenthal fail-safe N method gives us the number of potential missing studies we would need to include before the $p$-value became non-significant, large numbers (much bigger numbers than the amount of publications assessed in the meta-analysis) suggest absence of bias. In funnel plots, the presence of strong the asymmetries suggest bias. The funnel plots are shown in Annex B.

\subsection{Results}

\subsubsection{Overall results}

53 publications (Annex C) were finally included in the meta-analysis incorporated an overall of 365 comparisons. These primary studies were conducted in ten countries encompassing each of the five principal European biogeographical regions. Most studies were carried out in the Mediterranean region (59\%) (Figure $1 \mathrm{~A}$ and $1 \mathrm{~B}$ ), and $61 \%$ of the studies focused on silvopastoral systems (Figure 1C). Approximately similar proportions of publications focused on provisioning services, supporting and regulating services, and biodiversity (Figure 1D). 

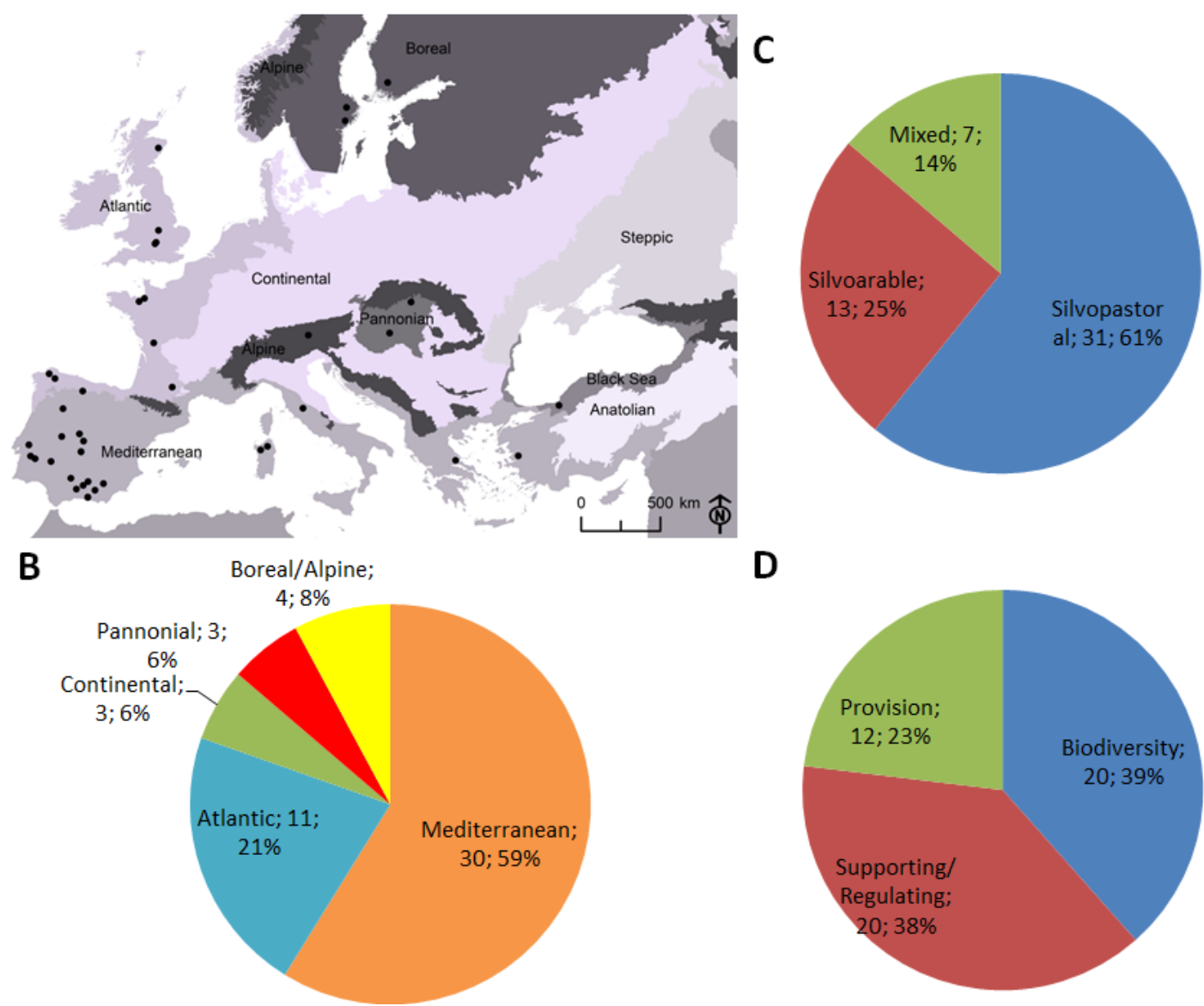

D

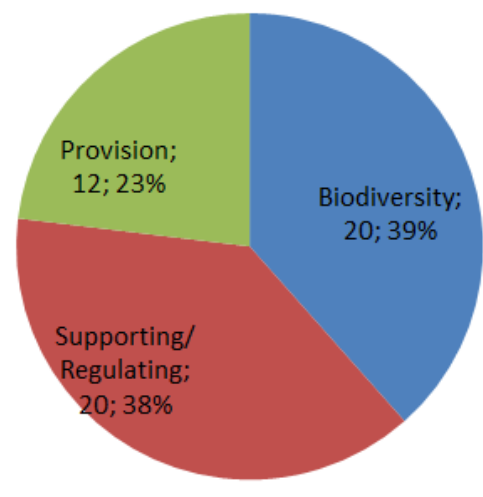

Figure 1. A. Geographic distribution of the case study sites B. the number and proportion of publications per region. C. The number and proportion of publications per agroforestry system type. D. the number and proportion of publications focused on provisioning, supporting/regulating ecosystem services, and biodiversity. Information in the pie charts: number of studies; percentage of studies.

The meta-analysis for the whole data-set using response ratios also revealed a significant positive effect of agroforestry on ecosystem service provision (mean effect size $=0.454 ; 95 \%$ confidence interval $=0.393$ to 0.516 ; Table $4 \mathrm{~A}$ ). Heterogeneity values reveal high diversity in study outcomes, methodologies and indicators used $(Z=1070 ; p<0.01)$. This pattern was visually confirmed in the funnel plot (Annex B). Fail safe number analysis showed no effect of publication bias (fail safe number $=1054288.4)$.

\subsubsection{Explanatory variables results}

In every subgroup analysis, the random-effect model for the different explanatory variables revealed a significant positive effect of agroforestry (Table 4B-J). When compared with conventional agriculture and forestry, agroforestry had a significant positive effect on soil fertility/nutrient cycling, erosion control, and biodiversity (mean effect size $=0.426 ; 95 \%$ confidence intervals $=0.382$ to 0.469 ; Figure 2; Table 4B). There were non-significant effects of agroforestry on food and timber production. The only significant negative effect of agroforestry was on biomass production (Figure 2; Table 4B). 


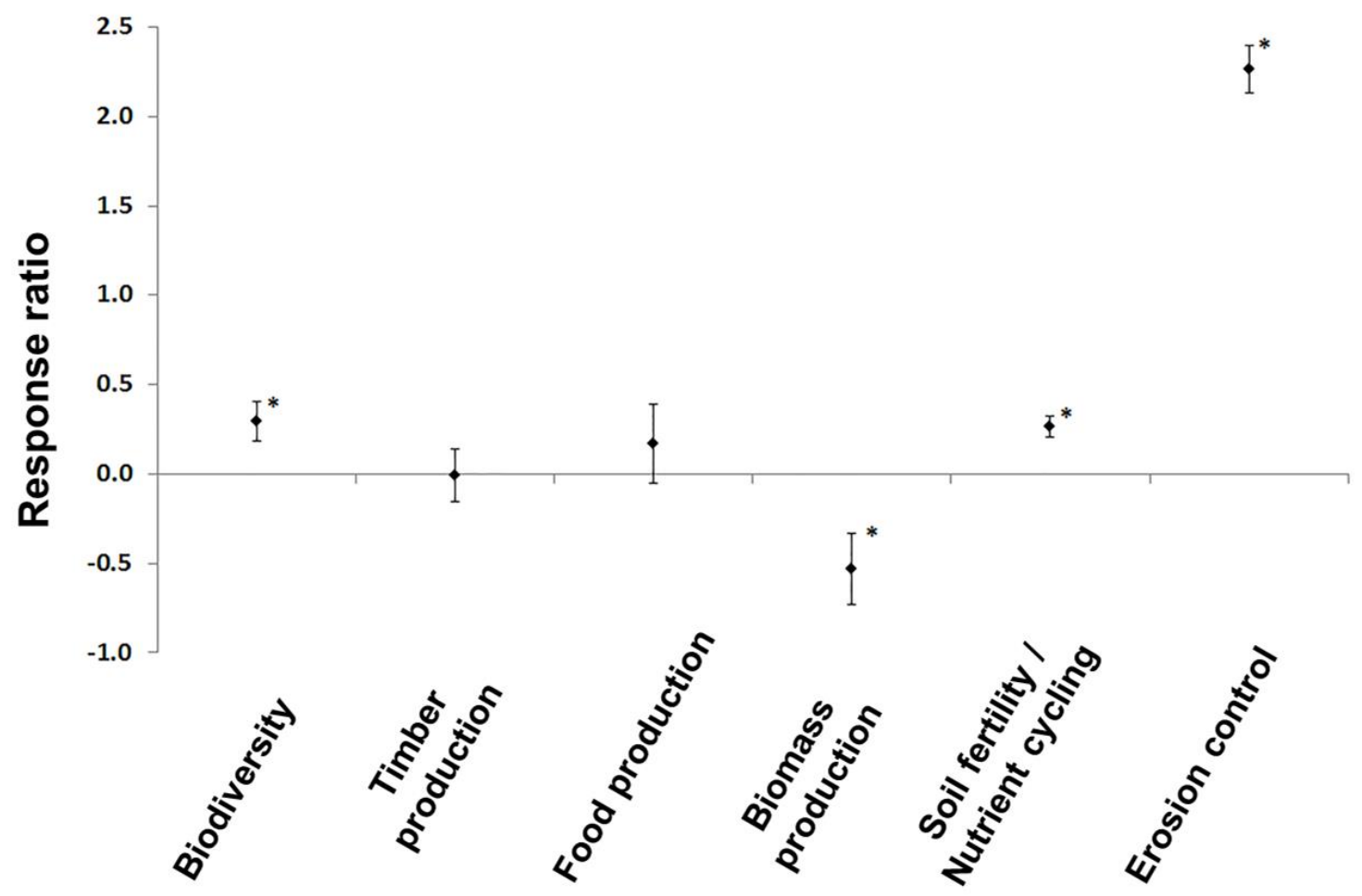

Figure 2. Mean effect size (response ratios) of agroforestry on different ecosystem service categories. ${ }^{*} E f f e c t$ sizes differed significantly from zero $(p<0.05)$.

Among the woody species used in European agroforestry, olive trees, followed by chestnut, walnuts and cherry species had highly significant positive effects (Figure 3A; Table 4F). Conifers were the only group that displayed a strong negative effect, whilst species such as poplar, willow, and ash showed negative but non-significant effects. We found strong increases in ecosystem service provision in studies that were performed at landscape $\left(1-1000 \mathrm{~km}^{2}\right)$ and regional $\left(>1000 \mathrm{~km}^{2}\right)$ scales (Figure 3B; Table 4E). 

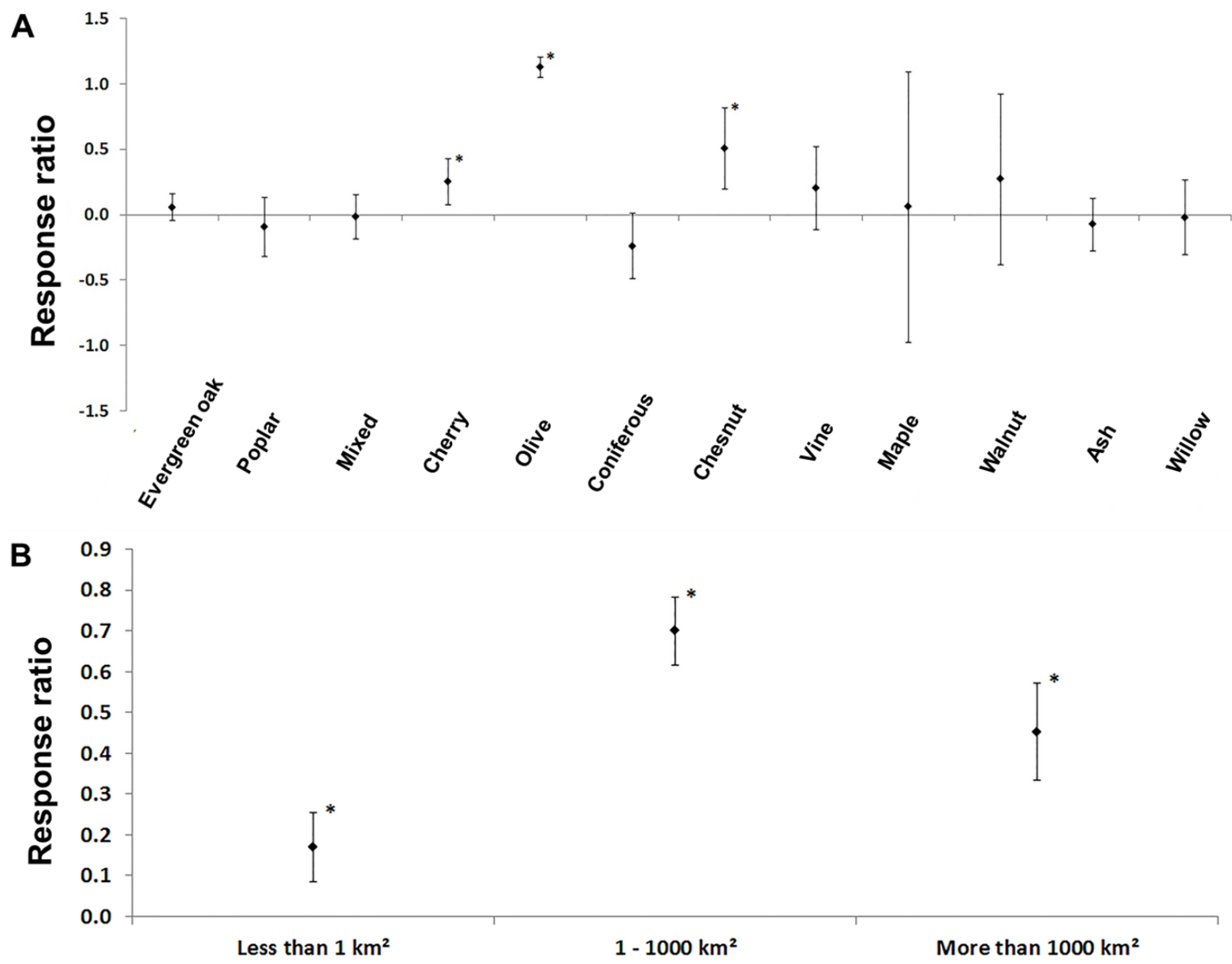

Figure 3. Mean effect size (response ratios) of agroforestry depending on: A. Main woody species. B. Study scale. ${ }^{*}$ Effect sizes differed significantly from zero $(p<0.05)$.

Both silvopasture and silvoarable systems had significant positive effects on erosion control and soil fertility but only silvopasture systems had a significant positive effect on biodiversity and a significant negative effect on biomass production (Figure 4A; Table 4B). For mixed systems, the analysis did not show clear positive or negative outcomes. In terms of the different comparators, agroforestry showed significant benefits in erosion control, biodiversity and soil fertility relative to forestry, and significant reductions in biomass production relative to both forestry and pasture. The responses of other ecosystem services were not significantly different from zero (Figure 4B; Table 4C). 

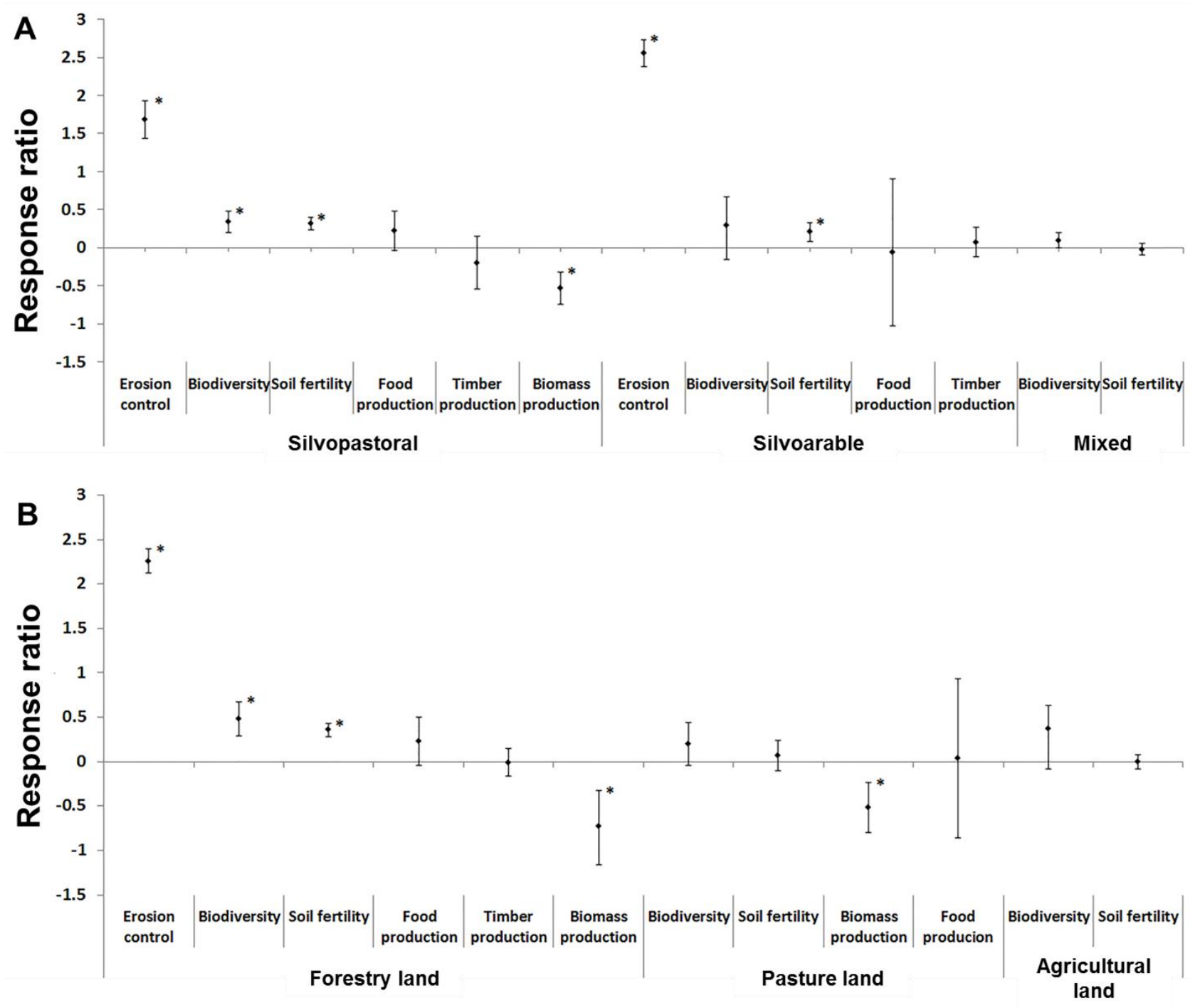

Figure 4. Mean effect size (response ratios) of agroforestry on different ecosystem services, differentiated according to: A. broad types of agroforestry, and B. comparator systems used. Here, positive effects refer to positive effect of agroforestry when compared to alternative land-use system. ${ }^{*}$ Effect sizes differed significantly from zero $(p<0.05)$.

Overall, significantly positive effects of agroforestry on biodiversity and ecosystem services were observed for the Mediterranean and Pannonian biogeographical regions; the effects of agroforestry in the Continental, Alpine and Boreal regions were not significant (Figure 5A; Table 4G). In line with this, there was a trend that the ecosystem service benefit of agroforestry tended to decrease with precipitation (slope $=-0.001 \mathrm{~mm}-1$; Figure $5 \mathrm{~B}$; Table $4 \mathrm{I}$ ) and increase with temperature (slope $=0.164$ ${ }^{\circ} \mathrm{C}-1$; Figure $5 \mathrm{C}$; Table $4 \mathrm{H}$ ), but the effects were not clear enough to infer an influence. 

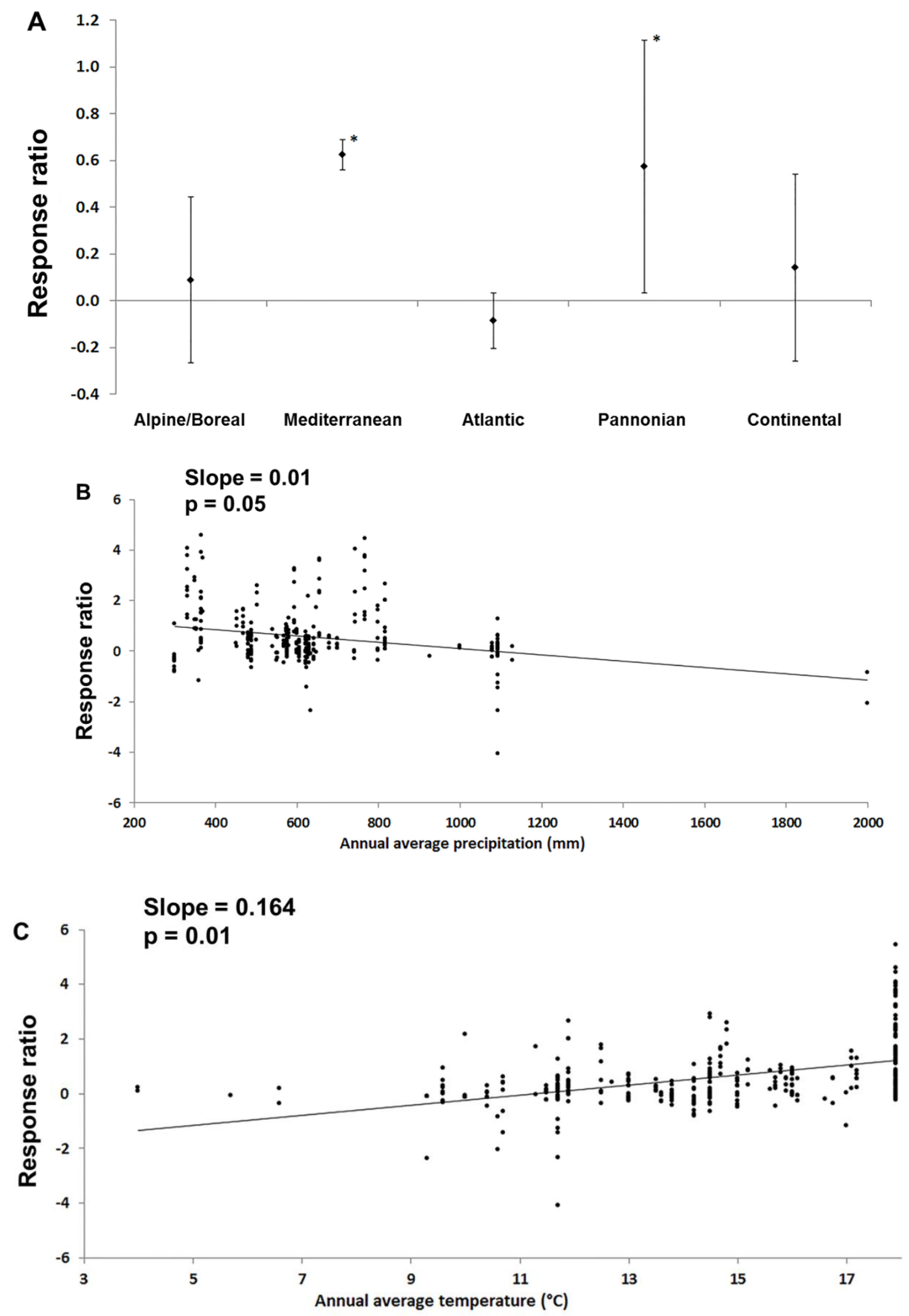

Figure 5. A. Mean effect size (response ratios) of agroforestry depending on the biogeographic region. B. Linear relationship between the annual average precipitation $(\mathrm{mm})$ and the effect size of ecosystem service provision. C. Linear relationship between the annual average temperature $\left({ }^{\circ} \mathrm{C}\right)$ and the effect size of ecosystem service provision. * Effect sizes differed significantly from zero.

The specific subgroup meta-analysis for biodiversity using the Hedges' $g$ as effect size index showed a significant positive effect of agroforestry systems on biodiversity (Figure 2), meaning that species richness and abundance were higher in agroforestry systems than in specialized agricultural and 
forestry systems (Table $4 \mathrm{~J} ; \mathrm{g}=0.874 ; 95 \%$ confidence interval $=0.532$ to 1.215 ). In this case, heterogeneity values revealed again large variation in the study outcomes $(Z=139 ; p<0.01)$ but less heterogeneity than the rest of the explanatory variables analyzed. This smaller value in heterogeneity is in part explained by the effect size index employed and in part because of the relatively homogeneity in the indicators used to assess biodiversity in the literature. The funnel plot showed no big asymmetries (Annex B) and the fail safe number analysis showed no publication bias (fail safe number $=2484.6$ ). The random-effect models revealed a positive trend of agroforestry in all the taxa, but the effect was only significant for birds (Figure 6; Table 4J).

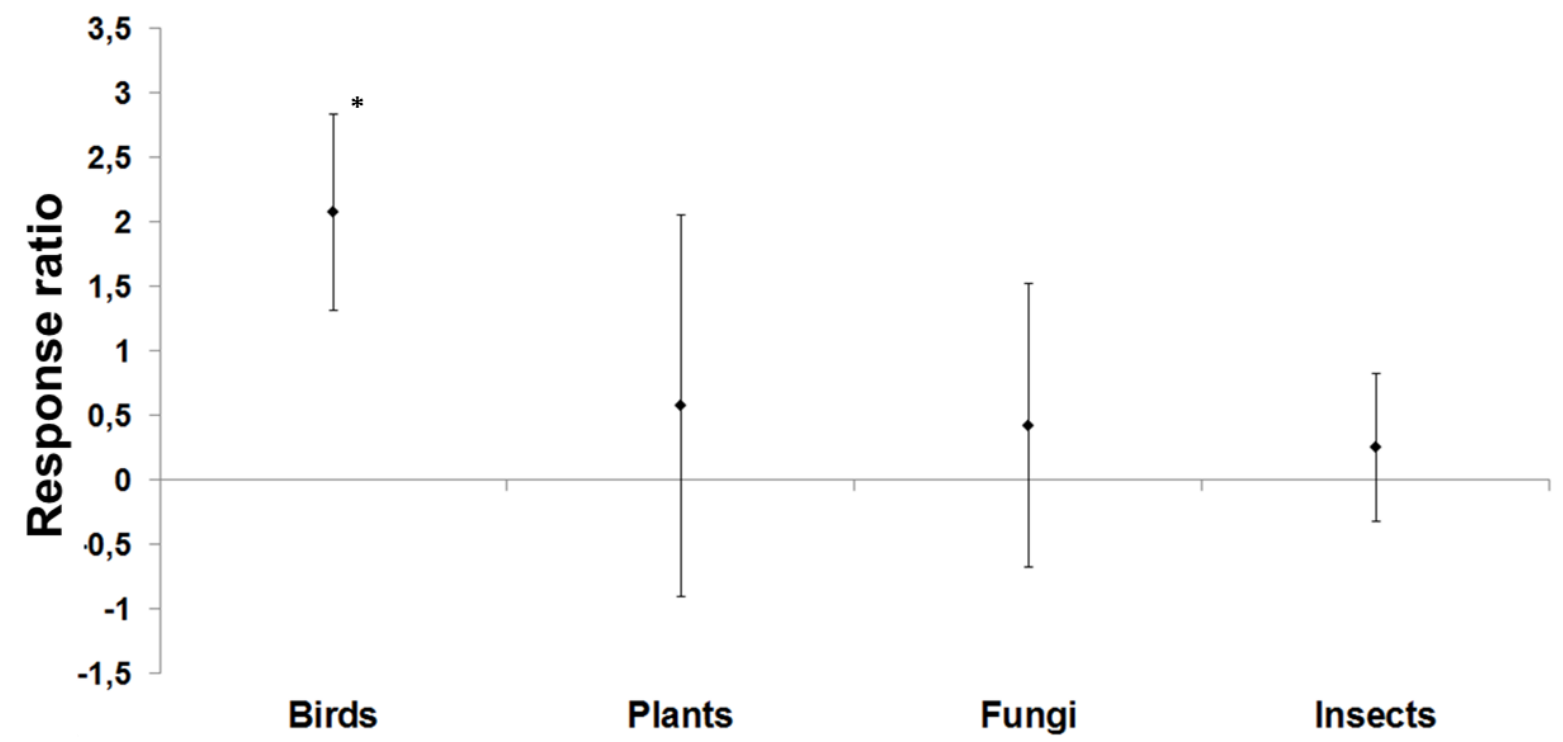

Fig. 6. Mean effect size (response ratios) of agroforestry on biodiversity depending on the taxon studied. ${ }^{*}$ Effect sizes differed significantly from zero. 
Table 4. Summary results of the meta-analysis. Effect size significantly different from zero $(p<0.01)$ is highlighted

\begin{tabular}{|c|c|c|c|c|c|c|}
\hline Moderator $(\mathbf{Q} ; \mathbf{P})$ & $\begin{array}{l}\text { Effect } \\
\text { size }\end{array}$ & $\begin{array}{l}\text { Standard } \\
\text { error }\end{array}$ & $\mathbf{Z}$ & $\begin{array}{l}95 \% \mathrm{Cl} \\
\text { Lower }\end{array}$ & $\begin{array}{l}95 \% \mathrm{Cl} \\
\text { Upper }\end{array}$ & $\mathbf{N}$ \\
\hline $\begin{array}{l}\text { Overall analysis }^{\mathrm{A}} \\
\text { Ovis }\end{array}$ & 0.454 & 0.115 & 1070 & 0.393 & 0.516 & 360 \\
\hline $\begin{array}{c}\mathrm{B} \\
\text { Ecosystem service }(951.54 ; 0.01)\end{array}$ & 0.426 & 0.144 & 1975 & 0.382 & 0.470 & 360 \\
\hline $\begin{array}{l}\text { Timber production } \\
\text { Food production } \\
\text { Biomass production } \\
\text { Soil fertility / Nutrient cycling } \\
\text { Erosion control } \\
\text { Biodiversity }\end{array}$ & $\begin{array}{r}-0.009 \\
0.173 \\
-0.532 \\
\\
0.261 \\
2.234 \\
0.297 \\
\end{array}$ & $\begin{array}{l}0.088 \\
0.016 \\
0.111 \\
\\
0.108 \\
1.552 \\
0.152 \\
\end{array}$ & & $\begin{array}{l}-0.158 \\
-0.049 \\
-0.729 \\
\\
0.200 \\
2.104 \\
0.187 \\
\end{array}$ & $\begin{array}{r}0.142 \\
0.395 \\
-0.334 \\
\\
0.322 \\
2.364 \\
0.407 \\
\end{array}$ & $\begin{array}{r}28 \\
19 \\
20 \\
\\
171 \\
57 \\
65\end{array}$ \\
\hline $\begin{array}{lll} & C & \\
\text { Agroforestry } & \text { system } \\
0.001) & & \end{array}$ & 0.449 & 0.115 & 1214 & 0.391 & 0.506 & 360 \\
\hline $\begin{array}{l}\text { Silvoarable } \\
\text { Silvopastoral } \\
\text { Mixed }\end{array}$ & $\begin{array}{l}0.772 \\
0.324 \\
0.061\end{array}$ & $\begin{array}{l}0.764 \\
0.329 \\
0.014 \\
\end{array}$ & & $\begin{array}{r}\mathbf{0 . 6 7 0} \\
\mathbf{0 . 2 5 1} \\
-0.180 \\
\end{array}$ & $\begin{array}{l}0.875 \\
0.397 \\
0.302 \\
\end{array}$ & $\begin{array}{r}122 \\
218 \\
20 \\
\end{array}$ \\
\hline $\begin{array}{c}\text { D } \\
\text { Comparator (123.77; 0.001) }\end{array}$ & 0.439 & 0.116 & 1478 & 0.387 & 0.490 & 358 \\
\hline $\begin{array}{l}\text { Agricultural land } \\
\text { Pasture land } \\
\text { Forestry land }\end{array}$ & $\begin{array}{r}0.097 \\
-0.015 \\
\mathbf{0 . 6 3 6} \\
\end{array}$ & $\begin{array}{l}0.020 \\
0.271 \\
\mathbf{0 . 2 9 2}\end{array}$ & & $\begin{array}{r}-0.094 \\
-0.122 \\
\mathbf{0 . 5 7 4} \\
\end{array}$ & $\begin{array}{l}0.288 \\
0.092 \\
0.699\end{array}$ & $\begin{array}{r}27 \\
82 \\
249 \\
\end{array}$ \\
\hline $\begin{array}{c}E \\
\text { Study scale }(54.14 ; 0.01)\end{array}$ & 0.181 & 0.099 & 924 & 0.141 & 0.221 & 303 \\
\hline $\begin{array}{c}\mathrm{F} \\
\text { Woody element }(224.12 ; 0.001)\end{array}$ & 0.176 & 0.100 & 1318 & 0.143 & 0.209 & 302 \\
\hline $\begin{array}{l}\text { Biogeographic } \text { G region }(62.17 ; \\
0.02)\end{array}$ & 0.181 & 0.099 & 937 & 0.141 & 0.221 & 303 \\
\hline $\begin{array}{c}\mathrm{H} \\
\text { Temperature Intercept }(-1.810)\end{array}$ & 0.164 & 0.184 & 879 & 0.463 & 0.602 & 314 \\
\hline $\begin{array}{c}\text { I } \\
\text { Precipitation Itercept (1.176) }\end{array}$ & -0.001 & 0.124 & 879 & 0.463 & 0.602 & 314 \\
\hline J J & 0.874 & 0.282 & 139 & 0.532 & 1.215 & 65 \\
\hline $\begin{array}{l}\text { Fungi } \\
\text { Arthropods } \\
\text { Plants } \\
\text { Birds }\end{array}$ & $\begin{array}{l}0.422 \\
0.539 \\
0.575 \\
2.068\end{array}$ & $\begin{array}{r}1.115 \\
2.04 \\
10.72 \\
2.04\end{array}$ & & $\begin{array}{l}-0.675 \\
-0.321 \\
-0.904 \\
\mathbf{1 . 3 0 9}\end{array}$ & $\begin{array}{l}1.520 \\
0.823 \\
2.054 \\
2.828\end{array}$ & $\begin{array}{r}9 \\
25 \\
6 \\
16\end{array}$ \\
\hline
\end{tabular}

\subsection{Discussion}

Most attempts to summarize the effects of agroforestry have focused on tropical and subtropical ecosystems (Kwesiga et al., 2003; Schroth, 2004; Tscharntke et al., 2011), on specific agroforestry practices (De Beenhouwer et al., 2013; Riiser and Hansen, 2014; Tsonkova et al., 2012), or on individual ecosystem services (Lorenz and Lal, 2014; Poch and Simonetti, 2013; Rivest et al., 2013; Pumariño et al., 2015). This study is the first attempt to analyze the effect of agroforestry practices on a broad set of ecosystem services and taxonomic groups in Europe. It covers varied agro-climatic regions and a high variety of agroforestry, agricultural and forestry practices, addressed largely by the CAP.

Our meta-analysis shows an overall positive effect of agroforestry on biodiversity and ecosystem service provision. Hence our findings demonstrate that, when compared to conventional land uses 
such as grassland, arable land, or forests, agroforestry supports higher levels of biodiversity and ecosystem goods and services. This analysis confirms the basic premise of agroforestry science that land-use systems that are structurally and functionally more complex than either crop- or tree-based systems result in a greater structural diversity that entails a tighter coupling of nutrient cycles, soil retention, and increased biodiversity, not necessarily compromising productivity (Cannell et al., 1996; Lefroy et al., 1999; Nair, 2007). However, the variation within the results was high, especially regarding provisioning services, showing that the benefits of agroforestry are context related. This is, in part, a result of the methodology which included publications with different indicators and research designs in a single statistical analysis (cf. Rey Benayas et al., 2009). Variation can also arise because the benefits provided by agroforestry are dependent on the context and the choice of land use selected for the comparison.

\subsubsection{Effects on ecosystem services}

Our meta-analysis revealed that most of the ecosystem services included were positively influenced by agroforestry (Figure 2). Agroforestry seems particularly useful in controlling soil erosion, significantly reducing the surface-runoff of soil (Francia et al., 2006; Gómez et al., 2009; García-Ruiz et al., 2010). This is especially relevant in the vineyards and olive trees plantations found on droughtstressed sloping land in the Mediterranean Basin (Durán Zuazo and Pleguezuelo, 2008). Agroforestry also enhanced soil fertility and nutrient cycling. While the capability of agroforestry to improve soil fertility has been documented for the tropics (Pinho et al., 2012; Zake et al., 2015), our meta-analysis demonstrates similar effects of increased soil organic matter content and nutrient concentration levels in European agroforestry.

As expected, the effects of agroforestry on the supply of provisioning services (food, timber, and biomass production) are mixed, depending to a large degree on the specific parameters that are compared. Here, it is important to keep in mind that the studies included in our meta-analysis compared only individual provisioning service elements (e.g., woody biomass production or grass production), not the full amount of food, timber, or biomass produced. A key hypothesis in agroforestry is that productivity is higher than in other systems due to the complementary use of resources that allow the provision of more than one product (Carnell et al., 1996). Field experiments and modelling exercises that were performed in three European countries showed that agroforestry can increase overall yields by up to $40 \%$ relative to monoculture arable and woodland systems (Graves et al., 2007). In general, our meta-analysis shows that agroforestry can provide similar levels of timber as forestry, and similar levels of food production as pasture land. One reason why this is possible is that the different components of an agroforestry can be partly complementary in their use of solar radiation and water (Smith et al. 2012). Surprisingly our meta-analysis suggests that agroforestry reduced biomass production in relation to forestry and pasture (Figure 4). These results suggest that the competition for resources result in a reduction of biomass production. However, biomass results should be taken with caution as some of the authors that found such effects (LópezDíaz et al., 2011; Pereira et al., 2002) acknowledge the difficulty to assess productivity in agroforestry systems as the biomass usually considers only the woody or the non-woody elements of the system, but not both together, giving a partial assessment of the biomass production in the system.

Although the aim of this meta-analysis was to assess a wider range of ecosystem services provided by agroforestry, many ecosystem service categories could not be included in the analysis. The absence of cultural ecosystem services particularly stands out, probably due to the difficulties to measure them quantitatively (Hernández-Morcillo et al., 2013; Milcu et al., 2013). Similar difficulties with including cultural ecosystem services were found in previous meta-analyses that addressed ecosystem services (Rey Benayas et al., 2009; De Beenhouwer et al., 2013; Howe et al., 2014; Meli et al., 2014; Barral et al., 2015).

\subsubsection{Effects on biodiversity}

Our analysis shows a strong positive effect of agroforestry on biodiversity (Figure 2), which is in line with findings from other parts of the world (Schroth, 2004; Felton et al., 2010; De Beenhouwer et al., 
2013). The capacity of agroforestry to provide food, shelter, habitat, and other resources for multiple species has been documented (McAdam and McEnvoy, 2009; Jose, 2009) and is one of the main reasons why many agroforestry areas are protected under the Natura 2000 Directive (European Union, 1992) and are frequently recorded as High Nature Value farmlands (Paracchini et al., 2008). Plieninger et al. (2015) documented that almost a quarter of the natural habitat types listed in the Annex I of the Directive (European Union, 1992) refer to some extent to silvopastures.

However, the benefits of agroforestry differ among the studied taxa (Figure 6). We found a strongly positive effect for bird communities. This is in line with findings from Fischer et al. (2010) though in contrast to the findings from De Beenhouwer et al. (2013). The difference is probably a result of Beenhouwer et al. (2013) comparing agroforestry to natural forests and plantations in the tropics, while the comparison in our meta-analysis included tree-less grasslands and croplands which generally have lower structural and functional diversity than "natural" systems.

\subsubsection{Variation related to context factors}

The outcomes of the comparative analysis between agroforestry system types and between comparators showed a clear positive effect for both silvoarable and silvopastoral systems, though the effect size is stronger for silvoarable systems (Figure 4A). This illustrates the importance of the comparator systems: silvopastoral systems was particularly rich in biodiversity and ecosystem services (Plieninger et al., 2015), but many tree-less grassland have a high nature value as well (Veen et al., 2009). Silvoarable systems may provide these benefits to a lesser degree, but here the contrast (and by this the potential for improvements in biodiversity and ecosystem services) to monocultural cropping systems is particularly strong (de Klein and Eckard, 2008).

The comparator system was an important category as well, with a significant positive effect size for comparisons of agroforestry systems against pure forest systems (Figure 4B). Surprisingly, the effect of agroforestry is not so clear in comparisons to agricultural and pasture land, indicating that the benefits of incorporating agroforestry into a land-use system is context-related and might depend on the different elements combined in the system.

Our meta-analysis suggests that the benefits of agroforestry were most apparent with deciduous and/or hardwood species such as olives, walnut, chestnut, and cherry species (Figure 3A; Table 4F). This is in line with other studies (e.g., Verhulst et al., 2004; Martins et al., 2010; Chiti et al., 2011; Zuazo et al., 2014), and is probably linked to the opportunity for complementary resource use being greatest for deciduous species, or species that are traditionally planted at a wide spacing. In contrast, fast-growing conifer species typically devoted to timber or biomass production showed a negative effect size for agroforestry. However, many of the studies on conifer systems only assessed indicators for provisioning services (Gul and Avciouglu, 2004; Silva-Pando, 2002).

Our analysis also points to geographic differences, as effect sizes were highest in the Mediterranean and Pannonian regions of Europe (Figure 5A). Also, the bioclimatic conditions analysis followed the same pattern, with increased ecosystem service supply in areas where temperature is higher and precipitation is lower (Figure $5 \mathrm{~B}$ and $\mathrm{C}$ ). The increased ecosystem service provision in warmer and drier regions is consequence of the strong positive impact in the meta-analysis of results in publications assessing erosion control and nutrient cycling, extensively studied in the South of Europe. This result indicates that existing research highlights the benefits of agroforestry to moderate the effects of high temperatures and drought stress.

The study also shows that the positive effects of agroforestry on ecosystem services were more apparent at a landscape and regional-scale than at a farm-scale (Figure 3B). This has potentially important policy implications as it suggests that landscape- and regional-scale responses are more than just the sum of farm-scale responses. This is particularly relevant in the European context, where agri-environment interventions are often addressed at a farm-, rather than at a catchment or landscape-scale (Concepción et al., 2012; Plieninger et al., 2012). 
4.4.4 Limitations of the meta-analysis

Some considerations need to be taken into account when interpreting the results and conclusions of this study. The systematic literature search and the selected inclusion criteria might have not captured all relevant publications addressing the research question of the meta-analysis. The search terms might have missed important information in grey literature especially in non-English publications, and the requirement that the publication provided means, standard deviations and population numbers forced us to disregard many publications. Many publications that reported ecosystem service assessments could not be included as they were assessing a single land use and lacked any comparison. Finally, although key agroforestry practices and each European biogeographic region were represented, there is a geographic bias in our pool of primary studies. In the Mediterranean area, concerns related with desertification encourage research on soil erosion while in more temperate climates interest in timber production may be higher. When analyzing the overall results, this fragmented structure of the primary data should be taken into account, especially when focusing on trade-offs between ecosystem services.

\subsection{Conclusions and policy implications}

Our analysis demonstrates that agroforestry generally enhances biodiversity and ecosystem service provision relative to conventional agriculture and forestry in Europe. However, the substantial variation in results also highlights that the responses are dependent on biophysical and land-use conditions. In Atlantic and Continental Europe, intercropping in chestnut and walnut systems, or integrating trees in arable systems can increase soil fertility and enhance biodiversity whilst maintaining agricultural productivity. In Mediterranean Europe, the studied publications indicate, that integrating cover crops and/or grazed legumes in vineyards and olive monoculture plantations generally increases soil fertility and nutrient retention whilst reducing soil loss. At the same time, existing silvopastoral systems such as the French pré-verger and the Central European Streuobst (Eichhorn et al., 2006) should not be neglected. The meta-analysis also stresses the importance of promoting features and practices that act at a landscape scale, as in the case of hedgerows, which play an important role in landscape-scale biodiversity conservation (Aviron et al., 2005; Michel et al., 2007; Rollin et al., 2013) as well as in creating barriers for wind erosion, creating a favorable microclimate (Smith et al., 2012), increasing soil fertility (Chifflot et al., 2005) and controlling pests and diseases (Pumariño et al., 2015).

The CAP does provide options for national governments to support the establishment of new agroforestry systems. However national governments have been reluctant to take up this opportunity, and often the level and duration of funding is less than for afforestation projects. Our results suggest that policy measures to support European agroforestry could be particularly effective in addressing biodiversity and ecosystem services such as soil erosion and runoff control, and nutrient retention at a landscape level. Hence, land managers and national and regional policy makers should be aware of this response diversity when prioritizing measures to promote European agroforestry.

\section{Acknowledgements}

We acknowledge funding through Grant 613520 from the European Commission (Project AGFORWARD, 7th Framework Program).

\subsection{References}

Aviron, S., Burel, F., Baudry, J., Schermann, N., 2005. Carabid assemblages in agricultural landscapes: impacts of habitat features, landscape context at different spatial scales and farming intensity. Agric. Ecosyst. Environ. 108, 205-217. http://doi:10.1016/j.agee.2005.02.004 
Barral, M.P., Rey Benayas, J.M., Meli, P., Maceira, N.O., 2015. Quantifying the impacts of ecological restoration on biodiversity and ecosystem services in agroecosystems: A global meta-analysis. Agric. Ecosyst. Environ. 202, 223-231. http://doi:10.1016/j.agee.2015.01.009

Batáry, P., Báldi, A., Kleijn, D., Tscharntke, T., 2011. Landscape-moderated biodiversity effects of agri-environmental management: a meta-analysis. Proc. Biol. Sci. 278, 1894-902. http://doi:10.1098/rspb.2010.1923

Bilotta, G.S., Milner, A.M., Boyd, I., 2014. On the use of systematic reviews to inform environmental policies. Environ. Sci. Policy 42, 67-77. http://doi:10.1016/j.envsci.2014.05.010

Borenstein, M., 2007. Meta-Analysis Fixed effect vs. random effects [WWW Document]. URL https://www.meta-analysis.com/downloads/Metaanalysis\%20fixed\%20effect\%20vs\%20random\%20effects.pdf

Borenstein, M., Hedges, L.V., Higgins, J.P.T., Rothstein, H.R., 2009. Introduction to Meta-Analysis. John Wiley and Sons, West Sussex.

Cannell, M.G.R., Noordwijk, M.V.A.N., Ong, C.K., 1996. The central agroforestry hypothesis: the trees must acquire resources that the crop would not otherwise acquire. Agrofor. Syst. 27-31. http://doi:10.1007/BF00129630

Centre of Evidence-based Conservation. 2010. Guidelines for Systematic Review in Environmental Management. Version $4.0 \quad$ Environmental evidence: http://www.environmentalevidence.org/Authors.thm.

Chifflot, V., Bertoni, G., Cabanettes, A., Gavaland, A., 2005. Beneficial effects of intercropping on the growth and nitrogen status of zoung wild cherry and hybrid walnut trees. Agrofor. Syst. 66, 13-21. http://doi:10.1007/s10457-005-3650-3

Chiti, T., Gardin, L., Perugini, L., Quaratino, R., Vaccari, F.P., Miglietta, F., Valentini, R., 2011. Soil organic carbon stock assessment for the different cropland land uses in Italy. Biol. Fertil. Soils 48, 917. http://doi:10.1007/s00374-011-0599-4

Concepción, E.D., Díaz, M., Kleijn, D., Báldi, A., Batáry, P., Clough, Y., Gabriel, D., Herzog, F., Holzschuh, A., Knop, E., Marshall, E.J.P., Tscharntke, T., Verhulst, J., 2012. Interactive effects of landscape context constrain the effectiveness of local agri-environmental management. J. Appl. Ecol. no-no. http://doi:10.1111/j.1365-2664.2012.02131.x

De Beenhouwer, M., Aerts, R., Honnay, O., 2013. A global meta-analysis of the biodiversity and ecosystem service benefits of coffee and cacao agroforestry. Agric. Ecosyst. Environ. 175, 1-7. http://doi:10.1016/i.agee.2013.05.003

den Herder, M. den, Burgess, P., Mosquera-Losada, M.R., Herzog, F., Hartel, T., Upson, M., Viholainen, I., Rosati, A., 2015. Preliminary stratification and quantification of agroforestry in Europe. Milestone Report 1.1 for EU FP7 Research Project: AGFORWARD 613520. 53 pp. www.agforward.eu

de Klein, C.A.M., Eckard, R.J., 2008. Targeted technologies for nitrous oxide abatement from animal agriculture. Aust. J. Exp. Agric. 48, 14-20. http://doi:10.1071/EA07217

Durán Zuazo, V.H., Pleguezuelo, C.R.R., 2008. Soil-erosion and runoff prevention by plant covers. A review. Agron. Sustain. Dev. 28, 65-86. http://doi:10.1051/agro:2007062

Eichhorn, M.P., Paris, P., Herzog, F., Incoll, L.D., Liagre, F., Mantzanas, K., Mayus, M., Moreno, G., Papanastasis, V.P., Pilbeam, D.J., Pisanelli, A., Dupraz, C., 2006. Silvoarable systems in Europe Past, present and future prospects. Agrofor. Syst. 67, 29-50. http://doi:10.1007/s10457-005-1111-7

EU Commission, 2011. Our life insurance, our natural capital: an EU biodiversity strategy to 2020. In: EU Commission (Ed.), Communication From the Commission to the European Parliament, the Council, the Economic and Social Committee and the Committee of the Regions (Brussels) 
European Union, 1992. Council Directive 92/43/EEC of 21 May 1992 on the conservation of natural habitats and of wild fauna and flora Official Journal of the European Union L206. 22.07.1992. pp. 750.

European Union, 2013. Regulation (EU) No. 1307/2013 of the European Parliament and of the Council of 17 December 2013 Establishing Rules for Direct Payments to Farmers Under Support Schemes within the Framework of the Common Agricultural Policy and Repealing Council Regulation (EC) No. 637/2008 and Council Regulation (EC) No. 73/2009. <http://eur-lex.europa.eu/LexUriServ/ LexUriServ.do?uri=OJ:L:2013:347:0608:0670:EN:PDF>. Official Journal of the European Union L 347. pp. 608-670..

Felton, A., Knight, E., Wood, J., Zammit, C., Lindenmayer, D., 2010. A meta-analysis of fauna and flora species richness and abundance in plantations and pasture lands. Biol. Conserv. 143, 545-554. http://doi:10.1016/j.biocon.2009.11.030

Fischer, J., Zerger, A., Gibbons, P., Stott, J., Law, B.S., 2010. Tree decline and the future of Australian farmland biodiversity. Proceedings of the National Academy of Sciences of the United States of America, 107(45), 19597-602. http://doi:10.1073/pnas.1008476107

Francia Martínez, J.R., Durán Zuazo, V.H., Martínez Raya, A., 2006. Environmental impact from mountainous olive orchards under different soil-management systems (SE Spain). Sci. Total Environ. 358, 46-60. http://doi:10.1016/i.scitotenv.2005.05.036

García-Ruiz, J.M., 2010. The effects of land uses on soil erosion in Spain: A review. Catena 81, 1-11. http://doi:10.1016/i.catena.2010.01.001

Gómez, J.A., Guzmán, M.G., Giráldez, J. V., Fereres, E., 2009. The influence of cover crops and tillage on water and sediment yield, and on nutrient, and organic matter losses in an olive orchard on a sandy loam soil. Soil Tillage Res. 106, 137-144. http://doi:10.1016/i.still.2009.04.008

Graves, A.R., Burgess, P.J., Palma, J.H.N., Herzog, F., Moreno, G., Bertomeu, M., Dupraz, C., Liagre, F., Keesman, K., van der Werf, W., de Nooy, A.K., van den Briel, J.P., 2007. Development and application of bio-economic modelling to compare silvoarable, arable, and forestry systems in three European countries. Ecol. Eng. 29, 434-449. http://doi:10.1016/i.ecoleng.2006.09.018

Gul, A., Avciouglu, R., 2004. Effects of some agroforestry applications on the rate of erosion and some other crop performances in marginal lands of the Aegean Region. Cah. Options Méditerranées 420, 417-420.

Gurevitch, J., Curtis, P.S., Jones, M.H., 2001. Meta-analysis in ecology. Adv. Ecol. Res. 32, 199-247. http://doi:10.1016/S0065-2504(01)32013-5

Hansen, T.R., Riiser, N.M., 2014. The Favorability of Rice-Agroforestry-A Meta-Analysis on Yield and Soil Parameters. Doctoral dissertation.

Hedges, L. V, Gurevitch, J., Curtis, P.S., 1999. The meta-analysis of response ratios in experimental ecology. Ecology 80, 1150-1156. http://doi:10.1890/0012-9658(1999)080[1150:TMAORR]2.0.CO;2

Hedges, L. V., Olkin, I., 1985. Statistical Methods for Meta-analysis. New York. Academic Press.

Hernández-Morcillo, M., Plieninger, T., Bieling, C., 2013. An empirical review of cultural ecosystem service indicators. Ecol. Indic. 29, 434-444. http://doi:10.1016/i.ecolind.2013.01.013

Howe, C., Suich, H., Vira, B., Mace, G.M., 2014. Creating win-wins from trade-offs? Ecosystem services for human well-being: A meta-analysis of ecosystem service trade-offs and synergies in the real world. Glob. Environ. Chang. 28, 263-275. http://doi:10.1016/j.gloenvcha.2014.07.005

Jose, S., 2009. Agroforestry for ecosystem services and environmental benefits: an overview. Agrofor. Syst. 76, 1-10. http://doi:10.1007/s10457-009-9229-7 
Jose, S., Gillespie, A.., Pallardi, S., 2004. Interspecific interactions in temperate agroforestry. Agrofor. Syst., Advances in Agroforestry 61, 237-255. http://doi:10.1007/978-94-017-2424-1

Kwesiga, F., Akinnifesi, F.K., Mafongoya, P.L., Mcdermott, M.H., Agumya, A., 2003. Agroforestry research and development in southern Africa during the 1990s: Review and challenges ahead. Agrofor. Syst. 59, 173-186. http://doi:10.1023/B:AGFO.0000005222.68054.38

Lefroy E.C., Hobbs R.J., Connor M.H.O., Pate J.S., 1999. What can agriculture learn from natural ecosystems? Agrofor. Syst. 45, 425- 438. http://doi:10.1023/A:1006293520726

López-Díaz, M.L., Rolo, V., Moreno, G., 2011. Trees' role in nitrogen leaching after organic, mineral fertilization: a greenhouse experiment. J. Environ. Qual. 40, 853-9. http://doi:10.2134/jeq2010.0165

Lorenz, K., Lal, R., 2014. Soil organic carbon sequestration in agroforestry systems. A review. Agron. Sustain. Dev. 34, 443-454. http://doi:10.1007/s13593-014-0212-y

Martins, A., Marques, G., Borges, O., Portela, E., Lousada, J., Raimundo, F., Madeira, M., 2010. Management of chestnut plantations for a multifunctional land use under Mediterranean conditions: effects on productivity and sustainability. Agrofor. Syst. 81, 175-189. http://doi:10.1007/s10457-010$\underline{9355-2}$

McAdam, J.H., Burgess, P.J., Graves, A.R., Rigueiro-Rodríguez, A., Mosquera-Losada, M.R., 2009. Classifications and Functions of Agroforestry Systems in Europe. In: Rigueiro-Rodríguez, A., McAdam, J., Mosquera-Losada, M.R. (eds.): Agroforestry in Europe Current Status and Future Prospects, 21-41. Springer Science + Business Media B.V., Dordrecht.

McAdam, J.H., McEvoy, 2009. The potential for silvopastoralism to enhance biodiversity on grassland farms in Ireland. In: Rigueiro-Rodríguez, A., McAdam, J., Mosquera-Losada, M.R. (eds.): Agroforestry in Europe Current Status and Future Prospects, 343-356. Springer Science + Business Media B.V., Dordrecht

Meli, P., Rey Benayas, J.M., Balvanera, P., Martínez Ramos, M., 2014. Restoration enhances wetland biodiversity and ecosystem service supply, but results are context-dependent: a metaanalysis. PLoS One 9, e93507. http://doi:10.1371/journal.pone.0093507

Michel, N., Burel, F., Legendre, P., Butet, A., 2007. Role of habitat and landscape in structuring small mammal assemblages in hedgerow networks of contrasted farming landscapes in Brittany, France. Landsc. Ecol. 22, 1241-1253. http://doi:10.1007/s10980-007-9103-9

Milcu, A.I., Hanspach, J., Abson, D., Fischer, J., 2013. Cultural ecosystem services: A literature review and prospects for future research. Ecol. Soc. 18, 44-77. http://doi:10.5751/ES-05790-180344

Millennium Ecosystem Assessment, 2005. Ecosystems and Human Well-being: Synthesis. Island Press, Washington, DC, $137 \mathrm{pp}$

Mosquera-Losada, M.R., McAdam, J.H., Romero-Franco, R., Santiago-Freijanes, J.J., RigueiroRodríguez, A., 2009. Definitions and components of agroforestry practices in Europe. In: RigueiroRodríguez, A., McAdam, J., Mosquera-Losada, M.R. (eds.): Agroforestry in Europe Current Status and Future Prospects, 3-19. Springer Science + Business Media B.V., Dordrecht.

Nair, P.R., 2007. The coming of age of agroforestry. J. Sci. Food Agric. 87, 1613-1619. http://doi:10.1002/jsfa.2897

Paillet, Y., Bergès, L., Hjältén, J., Odor, P., Avon, C., Bernhardt-Römermann, M., Bijlsma, R.J., De Bruyn, L., Fuhr, M., Grandin, U., Kanka, R., Lundin, L., Luque, S., Magura, T., Matesanz, S., Mészáros, I., Sebastià, M.-T., Schmidt, W., Standovár, T., Tóthmérész, B., Uotila, A., Valladares, F., Vellak, K., Virtanen, R., 2010. Biodiversity differences between managed and unmanaged forests: meta-analysis of species richness in Europe. Conserv. Biol. 24, 101-12. http://doi:10.1111/j.15231739.2009.01399.x 
Paracchini, M.L., Petersen, J.E., Hoogeveen, Y., Bamps, C., Burfield, I., van Swaay, C., 2008. High nature value farmland in Europe - an estimate of the distribution patterns on the basis of land cover and biodiversity data. JRC Scientific \& Technical Report EUR 23480 EN, 87 pp

Pereira E.L., Madeira M., Monteiro M.L., Raimundo F., 2002. Influence of ash tree (Fraxinus angustifólia, Vahl) on soil quality and herbaceous productivity in pastures of the Northeastern Portugal. Revista de Ciências Agrárias. Volume XXVII. 1: 347 - 360.

Pinho, R.C., Miller, R.P., Alfaia, S.S., 2012. Agroforestry and the improvement of soil fertility: A view from Amazonia. Appl. Environ. Soil Sci. 2012, 1-11. http://doi:10.1155/2012/616383

Plieninger, T., Hartel, T., Martín-López, B., Beaufoy, G., Bergmeier, E., Kirby, K., Montero, M.J., Moreno, G., Oteros-Rozas, E., Van Uytvanck, J., 2015. Wood-pastures of Europe: Geographic coverage, social-ecological values, conservation management, and policy implications. Biol. Conserv. 190, 70-79. http://doi:10.1016/j.biocon.2015.05.014

Plieninger, T., Hui, C., Gaertner, M., Huntsinger, L., 2014. The impact of land abandonment on species richness and abundance in the Mediterranean Basin: a meta-analysis. PLoS One 9, e98355. http://doi:10.1371/journal.pone.0098355

Plieninger, T., Schleyer, C., Schaich, H., Ohnesorge, B., Gerdes, H., Hernández-Morcillo, M., Bieling, C., 2012. Mainstreaming ecosystem services through reformed European agricultural policies. Conserv. Lett. 5, 281-288. http://doi:10.1111/j.1755-263X.2012.00240.x

Poch, T.J., Simonetti, J.A., 2013. Ecosystem services in human-dominated landscapes: Insectivory in agroforestry systems. Agrofor. Syst. 87, 871-879. http://doi:10.1007/s10457-013-9603-3

Pullin, A.S., Knight, T.M., 2009. Doing more good than harm - Building an evidence-base for conservation and environmental management. Biol. Conserv. 142, 931-934. http://doi:10.1016/i.biocon.2009.01.010

Pullin, A.S., Stewart, G.B., 2006. Guidelines for systematic review in conservation and environmental management. Conserv. Biol. 20, 1647-56. http://doi:10.1111/i.1523-1739.2006.00485.x

Pumariño, L., Sileshi, G.W., Gripenberg, S., Kaartinen, R., Barrios, E., Muchane, M.N., Midega, C., Jonsson, M., 2015. Effects of agroforestry on pest, disease and weed control: A meta-analysis. Basic Appl. Ecol. http://doi:10.1016/j.baae.2015.08.006

Rey Benayas, J.M., Newton, A.C., Diaz, A., Bullock, J.M., 2009. Enhancement of biodiversity and ecosystem services by ecological restoration: a meta-analysis. Science 325, 1121-4. http://doi:10.1126/science.1172460

Rivest, D., Paquette, A., Moreno, G., Messier, C., 2013. A meta-analysis reveals mostly neutral influence of scattered trees on pasture yield along with some contrasted effects depending on functional groups and rainfall conditions. Agric. Ecosyst. Environ. 165, 74-79. http://doi:10.1016/j.agee.2012.12.010

Rollin, O., Bretagnolle, V., Decourtye, A., Aptel, J., Michel, N., Vaissière, B.E., Henry, M., 2013. Differences of floral resource use between honey bees and wild bees in an intensive farming system. Agric. Ecosyst. Environ. 179, 78-86. http://doi:10.1016/j.agee.2013.07.007

Rosenberg, M.S., Adams, D., Gurevitch, J., 2000. Statistical Software for Meta-Analysis with resampling Tests. Sinauer Associates Inc, US. Pp. 1-64

Rosenthal, R., 1979. The file drawer problem and tolerance for null results. Psychol. Bull. 86, 638641. http://doi:10.1037/0033-2909.86.3.638

Schneiders, A., Van Daele, T., Van Landuyt, W., Van Reeth, W., 2012 Biodiversity and ecosystem services: Complementary approaches for ecosystem management? Ecological Indicators 21: 123133. http://doi:10.1016/i.ecolind.2011.06.021 
Schroth, G., da Fonseca, A.B., Harvey, C.A., Gascon, C., Vasconcelos, H.L. \& Izac, A.M.N., 2004. Agroforestry and Biodiversity Conservation in Tropical Landscapes. Island Press, Washington, USA.

Silva-Pando, F., 2002. Pasture production in a silvopastoral system in relation with microclimate variables in the Atlantic coast of Spain. Agrofor. Syst. 203-211. http://doi:10.1023/A:1021359817311

Smith, J., Pearce, B.D., Wolfe, M.S., 2012. Reconciling productivity with protection of the environment: Is temperate agroforestry the answer? Renew. Agric. Food Syst. 28, 80-92. http://doi:10.1017/S1742170511000585

Stewart, G., 2010. Meta-analysis in applied ecology. Biol. Lett. 6, 78-81. http://doi:10.1098/rsbl.2009.0546

Tscharntke, T., Clough, Y., Bhagwat, S. a., Buchori, D., Faust, H., Hertel, D., Hölscher, D., Juhrbandt, J., Kessler, M., Perfecto, I., Scherber, C., Schroth, G., Veldkamp, E., Wanger, T.C., 2011. Multifunctional shade-tree management in tropical agroforestry landscapes - a review. J. Appl. Ecol. 48, 619-629. http://doi:10.1111/j.1365-2664.2010.01939.x

Tsonkova, P., Böhm, C., Quinkenstein, A., Freese, D., 2012. Ecological benefits provided by alley cropping systems for production of woody biomass in the temperate region: a review. Agrofor. Syst. 85, 133-152. http://doi:10.1007/s10457-012-9494-8

UK NEA (UK National Ecosystem Assessment), 2011. The UK National Ecosystem Assessment: Synthesis of the Key Ffindings. UNEP-WCMC, Cambridge.

Van Zanten, B.T., Verburg, P.H., Espinosa, M., Gomez-y-Paloma, S., Galimberti, G., Kantelhardt, J., Kapfer, M., Lefebvre, M., Manrique, R., Piorr, A., Raggi, M., Schaller, L., Targetti, S., Zasada, I., Viaggi, D., 2013. European agricultural landscapes, common agricultural policy and ecosystem services: a review. Agron. Sustain. Dev. 34, 309-325. http://doi:10.1007/s13593-013-0183-4

Veen, P., Jefferson, R., de Smidt, J., van der Straaten, J., 2009. Grasslands in Europe of high nature value. KNNV Publishing (Zeist).

Verhulst, J., Báldi, A., Kleijn, D., 2004. Relationship between land-use intensity and species richness and abundance of birds in Hungary. Agric. Ecosyst. Environ. 104, 465-473. http://doi:10.1016/j.agee.2004.01.043

Zake, J., Pietsch, S.A., Friedel, J.K., Zechmeister-Boltenstern, S., 2015. Can agroforestry improve soil fertility and carbon storage in smallholder banana farming systems? J. Plant Nutr. Soil Sci. 178, 237249. http://doi:10.1002/jpln.201400281

Zuazo, V.H.D., Pleguezuelo, C.R.R., Tavira, S.C., 2014. Linking Soil Organic Carbon Stocks to Landuse Types in a Mediterranean Agroforestry Landscape. Journal of Agricultural Science and Technology 16, 667-679. 
ANNEX A for Torralba et al (2016): Review Protocol - Do European agroforestry systems provide more ES than other European agricultural or forestry practices?

\section{Objective}

The main objective is to determine, based on the published scientific literature, to what degree agroforestry systems increase the provision of ecosystem services in Europe compared to other agriculture and forestry systems (Population, Intervention, Comparator and Outcome are highlighted in Table 1). Specifically we raise the following research questions:

1. Does European agroforestry support higher levels of biodiversity and ecosystem services than monoculture agriculture or forestry?

2. What category/ies of ecosystem services and what species groups are most supported by agroforestry?

3. What differences arise between different kinds of agroforestry (e.g. silvoarable systems, silvopastoral agroforestry, agro-silvopastoral systems, buffer strips, and multipurpose trees systems)?

4. Are there physical and biological driven-forces for inter-sites differences?

Table 1. Population, Intervention, Comparator and Outcome

\begin{tabular}{|l|l|lrl|l|}
\hline Population & Intervention & Comparator & Outcome \\
\hline European & European agroforestry systems & $\begin{array}{l}\text { Non } \\
\text { systems: }\end{array}$ & $\begin{array}{r}\text { Agroforestry } \\
\text { forestry, }\end{array}$ & ES provision $(\uparrow$ or $\downarrow)$ \\
agricultural & & $\begin{array}{l}\text { agricultural } \\
\text { and }\end{array}$ & systems & & \\
and & & & & \\
livestock & & & & \\
land-use & & & & \\
systems & & & & \\
\hline
\end{tabular}

The aim of the search is to find all available studies containing data from field experiments assessing ES provision on European agroforestry systems. The main approach will be to conduct electronic searches in scientific databases. The systematic mapping will follow established guidelines (Pullin and Stewart 2006; Pullin and Knight 2009; Collaboration for Environmental Evidence 2013; Billota et al., 2014) and will be oriented by previous meta-analyses (Felton et al., 2010; Paillet et al., 2010; Batary et al., 2011; Meli et al., 2014; Plieninger et al., 2014)

Search terms and strings: scope will be performed by searching keywords that include aspects of the population, intervention and the outcome.

Scoping exercise revealed a weak power of general terms related with ecosystem services when looking for publications. Thus, search terms related with the population and intervention will stay always the same; while terms related with the outcome will change in the different steps depending on which ecosystem service we are scoping.

To refine the scoping results related with the intervention all European countries will be included in the search string with the following terms:

Europe* OR EU OR Albania OR Andorra OR Armenia OR Austria OR Azerbaijan OR Belarus OR Belgium OR "Bosnia and Herzegovina" OR Bulgaria OR Croatia OR Cyprus OR Czech* OR Denmark OR Estonia OR Finland OR France OR Georgia OR Germany OR Greece OR Hungary $O R$ Iceland OR Ireland OR Italy OR Kazakhstan OR Latvia OR Liechtenstein OR Lithuania OR Luxembourg OR Malta OR Moldova OR Monaco OR Montenegro OR Netherlands OR Norway OR Poland OR Portugal OR Romania OR Russia OR "San Marino" OR Serbia OR Slovak* OR Slovenia OR Spain OR Sweden OR Switzerland OR Macedonia OR Turkey OR Ukraine OR "United Kingdom" OR England OR Wales OR Scotland 
To address agroforestry systems, terms used to describe different agroforestry systems across Europe where included.

agroforestry OR silvoarable OR silvopastoral OR agrosilvopastoral OR "farm woodland" OR "forest farming " OR "forest grazing" OR "grazed forest*" OR "isolated trees" OR "scattered tree *" $O R$ "tree outside forest" $O R$ "farm tree *" OR woodlot* OR "timber tree system" OR dehesa OR montado OR "oak tree*" OR "olive tree*" OR "fruit tree*" OR pré-verger OR Streuobst OR pomarada* OR Hauberg OR Joualle OR "orchard system" OR "orchard intercropping" OR parkland" OR "alley cropping" OR "wooded pasture * OR "wood pasture *" OR pollarding OR "fodder tree*" OR pannage OR hedgerow* OR windbreak* OR "riparian woodland" OR "riparian buffer strip" "OR "buffer strip" OR "riparian buffer" OR "shelter belt"

To address the different ecosystem services, preliminary scoping exercises were performed to find out which ES have enough published literature to perform a meta-analysis. Only ES which were able to contribute with at least 7-10 publications were included in the final scoping exercise. This process revealed that the ecosystem services able to be included in the meta-analysis were those related with food and timber provision, ES related with soil formation, nutrient retention and erosion control, and biodiversity (Table 2).

Related with Provisioning services:

Product ${ }^{*}$ OR Provision*

Related with Soil services:

"Soil formation" OR "soil organic carbon" OR "soil carbon" OR "soil C" OR "soil organic C" OR $S O C$ OR "carbon pool" OR "carbon stock" OR "carbon storage" OR "soil organic matter" OR $S O M$, "carbon sequestrat" OR "C sequestrat" OR "Nutrient cycling" OR "Nutrient retention" OR "soil services" OR Nitrogen OR Phosphorus OR Erosion OR "soil loss".

Related with water quality ES:

"water quality" OR "water regulation" OR "water purification" OR "hydrological regulation"

Related with biodiversity:

Biodiversity OR richness OR "species abundance" OR "species composition" OR "biological diversity"

Electronic academic databases included in the search for relevant items include:

- $\quad$ ISI Web of Science.

- Scopus.

- Biosis.

- Cab Abstracts

- Google scholar (100 first results).

Table 2. Preliminary scoping exercise performed in July 2014

\begin{tabular}{|l|l|l|l|l|}
\hline & $\begin{array}{l}\text { Food and timber } \\
\text { provision }\end{array}$ & $\begin{array}{l}\text { Soil fertility/nutrient } \\
\text { cycling }\end{array}$ & $\begin{array}{l}\text { Erosion } \\
\text { control }\end{array}$ & Biodiversity \\
\hline $\begin{array}{l}\text { Hits (search in ISI } \\
\text { Web of knowledge }\end{array}$ & 2483 & 570 & 240 & 1813 \\
$\mathbf{7 / 2 0 1 4 )}$ & 186 & 43 & 218 \\
\hline $\begin{array}{l}\text { Title and keywords } \\
\text { riddle }\end{array}$ & 129 & 18 & \\
\hline
\end{tabular}

The numbers of articles retrieved, accepted and rejected will be noted down. Titles and abstracts will be stored in an Endnote database and duplicates will be removed. 


\section{Study inclusion and exclusion criteria}

Inclusion criteria will be first applied to the publication title and key words; after this filtering process the abstract will be addressed and finally the remaining publications will be filtered revising the whole document. Every time one case arise doubts about its inclusion, it will be included to the next stage for further evaluation (Pullin \& Stewart 2006)

To check for data quality and consistency of application of the inclusion criteria, another reviewer will go through the scoping exercise of the $10 \%$ of the references (Pullin \& Stewart 2006). The inclusion criteria will be performed by a stepwise process by applying the procedure describe in the table 3 .

Table 3. Inclusion criteria

\begin{tabular}{ll}
\hline 1. Agroforestry & Every kind of agroforestry system that follows the definition: Agroforestry is the \\
systems & oractice of deliberately integrating woody vegetation (trees or shrubs) with crop \\
& and/or animal production systems to benefit from the resulting ecological and \\
& zconomic interactions. This means that the following systems will be included: \\
& silvoarable systems, silvopastoral agroforestry, agro-silvopastoral systems, \\
& juffer strips and multipurpose trees systems.
\end{tabular}

\begin{tabular}{|c|c|}
\hline $\begin{array}{l}\text { pes } \\
\text { mparable } \\
\text { e }\end{array}$ & gion. \\
\hline ographical scope & $\begin{array}{l}\text { Farmland and forest systems in Europe. The study areas were limited to Europe } \\
\text { n a geographical context (e.g. including Switzerland and European parts of } \\
\text { Russia and Turkey) }\end{array}$ \\
\hline al & $\begin{array}{l}\text { Jnly studies that perform quantitative ecosystem service asse } \\
\text { orimary data. }\end{array}$ \\
\hline
\end{tabular}

\section{Data extraction strategy}

In order to perform a meta-analysis, available quantitative data related with each ES assessment will be extracted from every publication and those will be the response variables. For the dependent variables, a dataset will be performed with information about the ecosystem service studied and the indicator used to measure it. Observations of multiple ecosystem services and/or different study sites within one study will be included separately in the dataset and considered independently. For each observation, means, standard deviation and sample sizes will be extracted. If the data from the publications is valid, but summary statistics is not available in the text, it will be extracted from tables and graphs, or calculated from available raw data. If none of them are available, authors will be contacted and asked for the information.

As Independent variables, information about the study conditions will be extracted from each publication: kind of agroforestry system, kind of system compared and extent of the study area. Climatic and biogeographic information, which might not be included in the study region, will be taken from other data sources (WorldClim, and Google Earth) (Table 4). 
Table 4. Explanatory variables provided by primary studies and additional data sources that were included in the meta-analysis

\begin{tabular}{|c|c|c|}
\hline $\begin{array}{l}\text { Explanatory } \\
\text { variable }\end{array}$ & Description & Source \\
\hline $\begin{array}{l}\text { Agroforestry } \\
\text { system }\end{array}$ & $\begin{array}{l}\text { Agroforestry system on which the study was conducted: } \\
\text { silvoarable systems, silvopastoral systems, and mixed } \\
\text { systems }\end{array}$ & Primary studies \\
\hline Comparator & $\begin{array}{l}\text { Specialised land-use system that the publication uses to } \\
\text { compare the agroforestry system against. The three } \\
\text { categories employed were: agricultural land, pasture land, } \\
\text { and forestry land }\end{array}$ & Primary studies \\
\hline $\begin{array}{l}\text { Scale of the } \\
\text { study }\end{array}$ & Surface extent of the study area $\left(\mathrm{km}^{2}\right)$ & $\begin{array}{l}\text { Primary } \\
\text { studies/Google } \\
\text { Earth }\end{array}$ \\
\hline $\begin{array}{l}\text { Main woody } \\
\text { element }\end{array}$ & Main woody species of the agroforestry system & Primary studies \\
\hline Taxa studied $^{\mathbf{a}}$ & Taxa studied (Plants/arthropods/fungi/birds/worms) & Primary studies \\
\hline $\begin{array}{l}\text { Biogeographic } \\
\text { region }\end{array}$ & $\begin{array}{l}\text { Biogeographic region in which the study was conducted: } \\
\text { Boreal/Continental/Atlantic/Pannonian/Mediterranean/Alpine }\end{array}$ & Primary studies \\
\hline $\begin{array}{l}\text { Ecosystem } \\
\text { service } \\
\text { category }\end{array}$ & $\begin{array}{l}\text { Ecosystem service category assessed according to the } \\
\text { Millennium Ecosystem Assessment (2005) framework }\end{array}$ & Primary studies \\
\hline Temperature & Mean annual temperature $\left({ }^{\circ} \mathrm{C}\right)$ & $\begin{array}{l}\text { WorldClim/Primary } \\
\text { studies }\end{array}$ \\
\hline Precipitation & Mean annual precipitation $(\mathrm{mm})$ & $\begin{array}{l}\text { World clim/Primary } \\
\text { studies }\end{array}$ \\
\hline
\end{tabular}

a Studies in which biodiversity is assessed. 


\section{ANNEX B for Torralba et al (2016)}

Funnel plot of effect sizes between the variance and the Hedge's $g$ of biodiversity levels between agroforestry and non-agroforestry systems

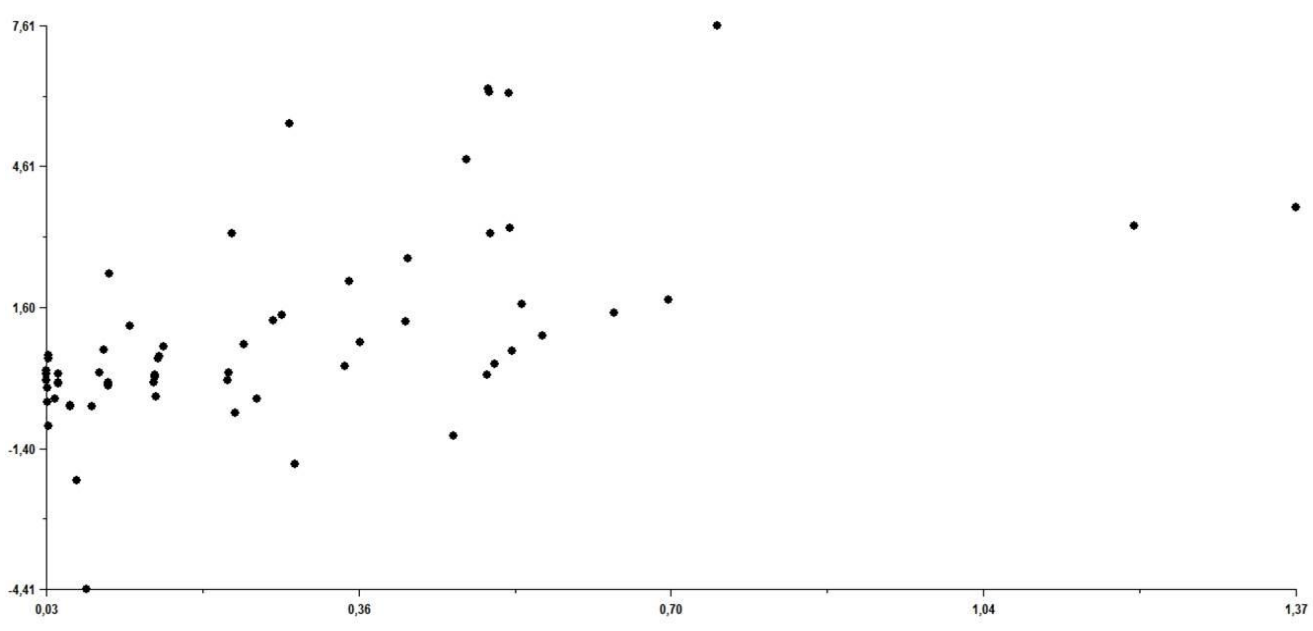

Funnel plot of effect sizes between the variance and the response ratios of ecosystem services between agroforestry and non-agroforestry systems

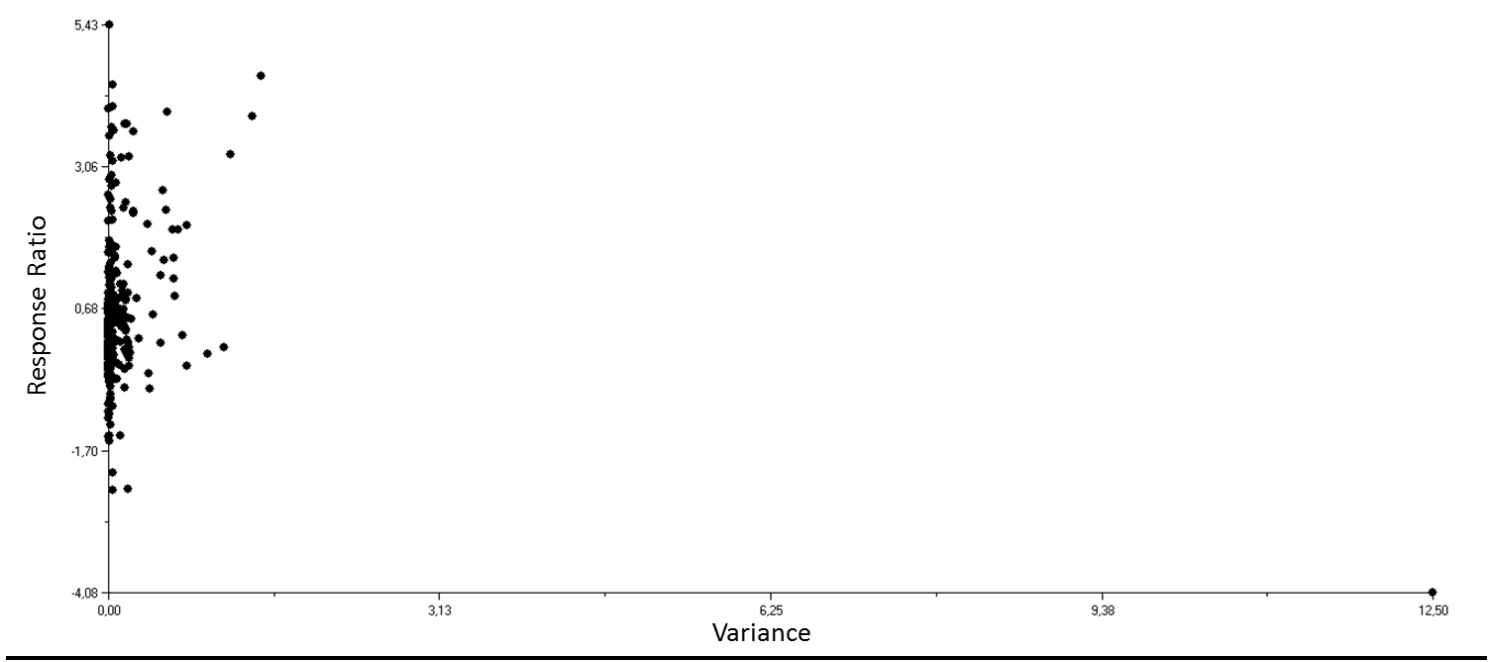


ANNEX C for Torralba et al (2016): List of publications

1. Ahnström, J., Berg, Å., \& Söderlund, H. (2008). Birds on farmsteads - effects of landscape and farming characteristics, (Mason 2000), 98-108.

2. Akbulut, S., Keten, A., \& Stamps, W. T. (2003). Effect of Alley Cropping on Crops and Arthropod Diversity in Duzce , Turkey, 269, 261-269.

3. Aragón, G., López, R., \& Martínez, I. (2010). Effects of Mediterranean dehesa management on epiphytic lichens. The Science of the Total Environment, 409(1), 116-22. doi:10.1016/j.scitotenv.2010.09.034

4. Aviron, S., Burel, F., Baudry, J., \& Schermann, N. (2005). Carabid assemblages in agricultural landscapes: impacts of habitat features, landscape context at different spatial scales and farming intensity. Agriculture, Ecosystems \& Environment, 108(3), 205-217. doi:10.1016/j.agee.2005.02.004

5. Balandier, P., \& Dupraz, C. (1999). Growth of widely spaced trees . A case study from young agroforestry plantations in France, 151-167.

6. Barriga, J. C., Lassaletta, L., Moreno, A. G., \& Journal, S. (2010). American Arachnological Society Ground-living spider assemblages from Mediterranean habitats under different management conditions, 38(2), 258-269.

7. Batáry, P., Orci, K. M., Báldi, A., Kleijn, D., Kisbenedek, T., \& Erdős, S. (2007). Effects of local and landscape scale and cattle grazing intensity on Orthoptera assemblages of the Hungarian Great Plain. Basic and Applied Ecology, 8(3), 280-290. doi:10.1016/j.baae.2006.03.012

8. Bauer, C. (2014) A comparative study of habitats on the abundance of oinvertebrates and their contribution of lysine and methionine to the diets of laying hens. Msc thesis. Department of Agriculture \& Business Management. Sruc Scotland's Rural College

9. Berg, Å. (2002). Composition and diversity of bird communities in Swedish farmland-forest mosaic landscapes: The amount of forest (at local and landscape scales) and occurrence of residual habitats at the local scale are shown to be the major factors influencing bird comm. Bird Study, 49(2), 153-165. doi:10.1080/00063650209461260

10. Burgess, P. J., Incoll, L. D., Corry, D. T., Beaton, A., \& Hart, B. J. (2004). Poplar ( Populus spp ) growth and crop yields in a silvoarable experiment at three lowland sites in England, 157-169.

11. Cárdenas, M., Castro, J., \& Campos, M. (2012). Short-Term Response of Soil Spiders to CoverCrop Removal in an Organic Olive Orchard in a Mediterranean Setting, 12(61), 1-18.

12. Chifflot, V., Bertoni, G., Cabanettes, a., \& Gavaland, a. (2006). Beneficial Effects of Intercropping on the Growth and Nitrogen Status of Young Wild Cherry and Hybrid Walnut Trees. Agroforestry Systems, 66(1), 13-21. doi:10.1007/s10457-005-3650-3

13. Chiti, T., Gardin, L., Perugini, L., Quaratino, R., Vaccari, F. P., Miglietta, F., \& Valentini, R. (2011). Soil organic carbon stock assessment for the different cropland land uses in Italy. Biology and Fertility of Soils, 48(1), 9-17. doi:10.1007/s00374-011-0599-4

14. Cotes, B., Campos, M., Pascual, F., García, P. a., \& Ruano, F. (2010). Comparing taxonomic levels of epigeal insects under different farming systems in Andalusian olive agroecosystems. Applied Soil Ecology, 44(3), 228-236. doi:10.1016/j.apsoil.2009.12.011

15. Ekroos, J., Kuussaari, M., Tiainen, J., Heliölä, J., Seimola, T., \& Helenius, J. (2013). Correlations in species richness between taxa depend on habitat, scale and landscape context. Ecological Indicators, 34, 528-535. doi:10.1016/j.ecolind.2013.06.015

16. Fontana, V., Radtke, A., Walde, J., Tasser, E., Wilhalm, T., Zerbe, S., \& Tappeiner, U. (2014). What plant traits tell us: Consequences of land-use change of a traditional agro-forest system on biodiversity and ecosystem service provision. Agriculture, Ecosystems \& Environment, 186, 4453. doi:10.1016/j.agee.2014.01.006

17. Francaviglia, R., Benedetti, A., Doro, L., Madrau, S., \& Ledda, L. (2014). Influence of land use on soil quality and stratification ratios under agro-silvo-pastoral Mediterranean management systems. Agriculture, Ecosystems \& Environment, 183, 86-92. doi:10.1016/j.agee.2013.10.026 
18. Francia Martínez, J. R., Durán Zuazo, V. H., \& Martínez Raya, A. (2006). Environmental impact from mountainous olive orchards under different soil-management systems (SE Spain). The Science of the Total Environment, 358(1-3), 46-60. doi:10.1016/j.scitotenv.2005.05.036

19. Giordani, P. (2010). Land use intensity drives the local variation of lichen diversity in Mediterranean ecosystems sensitive to desertification, 139-148.

20. Gómez, J. a., Guzmán, M. G., Giráldez, J. V., \& Fereres, E. (2009). The influence of cover crops and tillage on water and sediment yield, and on nutrient, and organic matter losses in an olive orchard on a sandy loam soil. Soil and Tillage Research, 106(1), 137-144. doi:10.1016/j.still.2009.04.008

21. Gul, A., \& Avciouglu, R. (2004). Effects of some agroforestry applications on the rate of erosion and some other crop performances in marginal lands of the Aegean Region, 420, 417-420.

22. Hernández, a. J., Lacasta, C., \& Pastor, J. (2005). Effects of different management practices on soil conservation and soil water in a rainfed olive orchard. Agricultural Water Management, 77(13), 232-248. doi:10.1016/j.agwat.2004.09.030

23. Howlett, D. S., Mosquera-Losada, M. R., Nair, P. K. R., Nair, V. D., \& Rigueiro-Rodríguez, A. (2011). Soil carbon storage in silvopastoral systems and a treeless pasture in northwestern Spain. Journal of Environmental Quality, 40(3), 825-32. doi:10.2134/jeq2010.0145

24. Hussain, M. Z., Otieno, D. O., Mirzae, H., Li, Y. L., Schmidt, M. W. T., Siebke, L., ... Tenhunen, J. D. (2009). CO2 exchange and biomass development of the herbaceous vegetation in the Portuguese montado ecosystem during spring. Agriculture, Ecosystems \& Environment, 132(1-2), 143-152. doi:10.1016/j.agee.2009.03.008

25. López-Díaz, M. L., Rolo, V., \& Moreno, G. (2011). Trees' role in nitrogen leaching after organic, mineral fertilization: a greenhouse experiment. Journal of Environmental Quality, 40(3), 853-9. doi:10.2134/jeq2010.0165

26. Lozano-García, B., \& Parras-Alcántara, L. (2013). Land use and management effects on carbon and nitrogen in Mediterranean Cambisols. Agriculture, Ecosystems \& Environment, 179, 208214. doi:10.1016/j.agee.2013.07.009

27. Martins, A., Marques, G., Borges, O., Portela, E., Lousada, J., Raimundo, F., \& Madeira, M. (2010). Management of chestnut plantations for a multifunctional land use under Mediterranean conditions: effects on productivity and sustainability. Agroforestry Systems, 81(2), 175-189. doi:10.1007/s10457-010-9355-2

28. Merckx, T., Marini, L., Feber, R. E., \& Macdonald, D. W. (2012). Hedgerow trees and extendedwidth field margins enhance macro-moth diversity: implications for management. Journal of Applied Ecology, 49(6), 1396-1404. doi:10.1111/j.1365-2664.2012.02211.x

29. Michel, N., Burel, F., Legendre, P., \& Butet, A. (2007). Role of habitat and landscape in structuring small mammal assemblages in hedgerow networks of contrasted farming landscapes in Brittany, France. Landscape Ecology, 22(8), 1241-1253. doi:10.1007/s10980-007-9103-9

30. Moreno Marcos, G., Obrador, J. J., García, E., Cubera, E., Montero, M. J., Pulido, F., \& Dupraz, C. (2007). Driving competitive and facilitative interactions in oak dehesas through management practices. Agroforestry Systems, 70(1), 25-40. doi:10.1007/s10457-007-9036-y

31. Moreno, G. (2008). Response of understorey forage to multiple tree effects in lberian dehesas. Agriculture, Ecosystems \& Environment, 123(1-3), 239-244. doi:10.1016/j.agee.2007.04.006

32. Nieto, O. M., Castro, J., \& Fernández-Ondoño, E. (2013). Conventional tillage versus cover crops in relation to carbon fixation in Mediterranean olive cultivation. Plant and Soil, 365(1-2), 321-335. doi:10.1007/s11104-012-1395-0

33. Nieto, O. M., Castro, J., \& Guzmán, G. (2012). Soil-Management Systems in the Olive Orchard and Influence on the Organic-Matter and Nutrient Contents, 105-112.

34. Pereira, E.L., Madeira, M., Monteiro, M.L., Raimundo, F. (2002). Influence of ash tree on soil quality and herbaceous productivity in pastures of the northeast Portugal.

35. Pereira, P., Godinho, C., Gomes, M., \& Rabaça, J. E. (2012). The importance of the surroundings: are bird communities of riparian galleries influenced by agroforestry matrices in SW Iberian Peninsula? Annals of Forest Science, 71(1), 33-41. doi:10.1007/s13595-012-0228-x 
36. Ramos, M. E., Benítez, E., García, P. a., \& Robles, A. B. (2010). Cover crops under different managements vs. frequent tillage in almond orchards in semiarid conditions: Effects on soil quality. Applied Soil Ecology, 44(1), 6-14. doi:10.1016/j.apsoil.2009.08.005

37. Ramos, M. E., Robles, A. B., Sánchez-Navarro, A., \& González-Rebollar, J. L. (2011). Soil responses to different management practices in rainfed orchards in semiarid environments. Soil and Tillage Research, 112(1), 85-91. doi:10.1016/j.still.2010.11.007

38. Rodrigues, M. Â., Lopes, J. I., Pavão, F. M., Cabanas, J. E., \& Arrobas, M. (2011). Effect of Soil Management on Olive Yield and Nutritional Status of Trees in Rainfed Orchards. Communications in Soil Science and Plant Analysis, 42(9), 993-1007. doi:10.1080/00103624.2011.562582

39. Rollin, O., Bretagnolle, V., Decourtye, A., Aptel, J., Michel, N., Vaissière, B. E., \& Henry, M. (2013). Differences of floral resource use between honey bees and wild bees in an intensive farming system. Agriculture, Ecosystems \& Environment, 179, 78-86. doi:10.1016/j.agee.2013.07.007

40. Rolo, V., López-Díaz, M. L., \& Moreno, G. (2012). Shrubs affect soil nutrients availability with contrasting consequences for pasture understory and tree overstory production and nutrient status in Mediterranean grazed open woodlands. Nutrient Cycling in Agroecosystems, 93(1), 89102. doi:10.1007/s10705-012-9502-4

41. Rolo, V., Rivest, D., López-Díaz, M. L., \& Moreno, G. (2014). Microhabitat effects on herbaceous nutrient concentrations at the community and species level in Mediterranean open woodlands: the role of species composition. Grass and Forage Science, 70(2), 219-228. doi:10.1111/gfs.12110

42. Ruiz-Mirazo, J., \& Robles, A. B. (2012). Impact of targeted sheep grazing on herbage and holm oak saplings in a silvopastoral wildfire prevention system in south-eastern Spain. Agroforestry Systems, 86(3), 477-491. doi:10.1007/s10457-012-9510-z

43. Seddaiu, G., Porcu, G., Ledda, L., Roggero, P. P., Agnelli, A., \& Corti, G. (2013). Soil organic matter content and composition as influenced by soil management in a semi-arid Mediterranean agro-silvo-pastoral system. Agriculture, Ecosystems \& Environment, 167, 1-11. doi:10.1016/j.agee.2013.01.002

44. Shvaleva, A., Costa e Silva, F., Costa, J. M., Correia, A., Anderson, M., Lobo-do-Vale, R., ... Cruz, C. (2013). Comparison of methane, nitrous oxide fluxes and CO2 respiration rates from a Mediterranean cork oak ecosystem and improved pasture. Plant and Soil, 374(1-2), 883-898. doi:10.1007/s11104-013-1923-6

45. Silva-Pando, F. (2002). Pasture production in a silvopastoral system in relation with microclimate variables in the atlantic coast of Spain, 203-211.

46. Smith, J., Leach, K., Gerrard, C., Padel, S. (2014) Assessment of an agroforestry system in terms of feed supply and miltifunctionality (D 3.2 Part 1) Deliverable Project no. 266367: Sustainable Organic and Low Imput Dairying"

47. Solomou, A. D., Sfougaris, A. I., Vavoulidou, E. M., \& Csuzdi, C. (2012). The effects of farming practices on earthworm dynamics in olive groves of central Greece. Zoology in the Middle East, 58(sup4), 119-126. doi:10.1080/09397140.2012.10648993

48. Stockan, J. a., Baird, J., Langan, S. J., Young, M. R., \& lason, G. R. (2014). Effects of riparian buffer strips on ground beetles (Coleoptera, Carabidae) within an agricultural landscape. Insect Conservation and Diversity, 7(2), 172-184. doi:10.1111/icad.12043

49. Taboada, A., Kotze, D. J., Tárrega, R., \& Salgado, J. M. (2006). Traditional forest management: Do carabid beetles respond to human-created vegetation structures in an oak mosaic landscape? Forest Ecology and Management, 237(1-3), 436-449. doi:10.1016/j.foreco.2006.09.077

50. Upson, M. a., \& Burgess, P. J. (2013). Soil organic carbon and root distribution in a temperate arable agroforestry system. Plant and Soil, 373(1-2), 43-58. doi:10.1007/s11104-013-1733-x

51. Verhulst, J., Báldi, A., \& Kleijn, D. (2004). Relationship between land-use intensity and species richness and abundance of birds in Hungary. Agriculture, Ecosystems \& Environment, 104(3), 465-473. doi:10.1016/j.agee.2004.01.043

52. Zuazo, V. H. D., Pleguezuelo, C. R. R., Panadero, L. A., Raya, a. M., Martínez, J. R. F., \& Rodríguez, B. C. (2009). Soil Conservation Measures in Rainfed Olive Orchards in South-Eastern 
Spain: Impacts of Plant Strips on Soil Water Dynamics. Pedosphere, 19(4), 453-464. doi:10.1016/S1002-0160(09)60138-7 